O. PIOTR SKONIECZNY OP

Wydział Prawa Kanonicznego

Uniwersytetu Papieskiego Jana Pawła II w Krakowie

\title{
PRZESTĘPSTWO CIĘŻSZE PRZECIWKO SZÓSTEMU PRZYKAZANIU DEKALOGU Z MAŁOLETNIM - UWAGI DE LEGE LATA I DE LEGE FERENDA
}

Treść: Zamiast wstępu: systematyka, czyli o przedmiocie ochrony kanonicznokarnej. - I. ZNAMIONA PRZEDMIOTOWE. - I.1. Znamię sprawcy, czyli przestępstwo indywidualne. - I.1.1. Tylko duchowny (przestępstwa indywidualne). - I.1.2. Problem sprawstwa innych wiernych. - I.1.2.1. Tradycja kanoniczna. - I.1.2.2. Obowiązujący stan prawny. - I.1.2.3. Wytyczne KEP z 2014 r. - I.1.3. Ciężkość kanoniczna przestępstwa a godność jego sprawcy. - I.2. Znamię czasownikowe. - I.2.1. Czynność wykonawcza przestępstwa. - 1.2.1.1. Szerokie rozumienie „przestępstwa przeciwko szóstemu przykazaniu Dekalogu”. - 1.2.1.2. Uwagi prawnoporównawcze. - 1.2.1.3. Przestępstwo okazjonalne, habitualne, trwałe? - I.2.2. Podmiot wykonawczy przestępstwa, czyli ofiara. - I.2.2.1. Uwagi ogólne i psychiatryczne. - I.2.2.2. Małoletni. - I.2.2.3. Osoba trwale ograniczona w używaniu rozumu. - I.2.3. Zbieg przestępstw. - II. ZNAMIONA PODMIOTOWE. - II.1. Zamiar bezpośredni - czy tylko? - II.1.1. Cum dolo. - II.1.2. Cum culpa - przeoczone konsekwencje różnicy między regulacją łacińską i wschodnią. - II.1.3. Cum culpa, czyli cum dolo eventuali - przeoczone różnice z regulacją polskiego kodeksu karnego. - II.2. Sylwetka psychologiczna pedofila a możliwość powołania się na chorobę psychiczną jako okoliczność wyłączającą lub zmniejszającą zawienienie czynu. - II.3. Inne okoliczności wyłączające lub zmniejszające zawinienie czynu. - II.3.1. Nieznajomość ustawy karnej. II.3.2. Zgoda ofiary. - II.3.3. Prowokacja ze strony małoletniego. - III. ZNAMIĘ LEGALNE I KARALNOŚĆ. - III.1. Znamię legalne, czyli zagrożenie karą przestępstw contra mores. - III.1.1. Dwa stopnie wymierzania sankcji 
karnej. - III.1.2. Wydalenie zakonnika z instytutu zakonnego. - III.1.3. Uwagi de lege ferenda - kara latae sententiae i przeszkoda do przyjęcia święceń? - III.2. Przedawnienie karnokanoniczne przestępstw contra mores. - III.3. Szczególne zagadnienia proceduralne. - Zakończenie.

\section{Zamiast wstępu: systematyka, czyli o przedmiocie ochrony kanonicznokarnej}

Wśród przestępstw przeciwko szóstemu przykazaniu Dekalogu należy wyróżnić przestępstwa cięższe (delicta graviora) przeciwko obyczajności (contra mores) z art. 6 SST/2010, a spośród nich - to, które jest popełniane z małoletnim (n. 1 art. 6 SST/2010). To właśnie przestępstwo jest przedmiotem niniejszych rozważań. Te rozważania mają charakter komentarza do regulacji obowiązującej w prawie kanonicznym (de lege lata), ale z wyraźnym poszukiwaniem pożądanego stanu prawnego w przyszłości (de lege ferenda). Ten drugi cel w szczególności wymusza w tym zakresie uwagi prawnoporównawcze z polskim kodeksem karnym².

Już na wstępie należy zauważyć szczególną ewolucję odnośnie do przedmiotu ochrony art. 6 SST/2010, śledząc umieszczenie tego przepisu w większych jednostkach redakcyjnych tekstów prawnych. Ustawodawca pierwszego kodeksu Kościoła z 1917 r. za przedmiot ochrony kan. $2359 \$ 2^{3}$ uznawał dobre obyczaje (boni

\footnotetext{
${ }^{1}$ Stan prawny na 1 sierpnia 2017 r. Artykuł jest poszerzoną wersją części referatu, wygłoszonego na konferencji popularnonaukowej organizowanej przez Wyższe Seminarium Misyjne Księży Sercanów w Stadnikach dnia 10 listopada 2016 r. Referat został złożony do druku w „Sympozjum”. Skrót SST/2010 oznacza: CoNGREGatio pro Doctrina Fidei, Normae de gravioribus delictis, 21.05.2010, „Acta Apostolicae Sedis" [dalej w skrócie: AAS] 102 (2010), s. 419-434.

${ }^{2}$ Zwanego dalej w skrócie: k.k.

${ }^{3}$ Can. 2359. - $\$ 1$. Clerici in sacris sive saeculares sive religiosi concubinarii, monitione inutiliter praemissa, cogantur ab illicito contubernio recedere et scandalum reparare suspensione a divinis, privatione fructuum officii, beneficii, dignitatis, servato praescripto can. 2176-2181.

$\$ 2$. Si delictum admiserint contra sextum decalogi praeceptum cum minoribus infra aetatem sexdecim annorum, vel adulterium, stuprum, bestialitatem, sodomiam, lenocinium, incestum cum consanguineis aut affinibus in primo gradu
} 
mores) ${ }^{4}$. Z kolei w kodeksie łacińskim z 1983 r. w kan. $1395^{5}$ nastąpiło przesunięcie akcentu na obowiązek celibatu kościelnego ${ }^{6}$. W końcu normy o delicta graviora powracają do tradycyjnego określenia przedmiotu ochrony, stanowiąc w art. $6 \$ 1$ SST/2010 in princ., że chodzi o przestępstwa przeciwko obyczajności (delicta contra mores). Nie wyklucza się przy tym szczególnego obowiązku duchownych wynikającego z ustawy o celibacie kościelnym (por. kan. $276 \$ 1$ oraz kan. 277 CIC; kan. 368 oraz kan. 373-374

exercuerint, suspendantur, infames declarentur, quolibet officio, beneficio, dignitate, munere, si quod habeant, priventur, et in casibus gravioribus deponantur.

$\$ 3$. Si aliter contra sextum decalogi praeceptum deliquerint, congruis poenis secundum casus gravitatem coerceantur, non excepta officii vel beneficii privatione, maxime si curam animarum gerant.

${ }^{4}$ Tytuł XIV Księgi V kodeksu prawa kanonicznego z 1917 r. (dalej w skrtócie: CIC/17) brzmiał bowiem: „De delictis contra vitam, libertatem, proprietatem, bonam famam ac bonos mores" (kursywa - P.S.).

${ }^{5}$ Can. $1395-\$ 1$. Clericus concubinarius, praeter casum de quo in can. 1394, et clericus in alio peccato externo contra sextum Decalogi praeceptum cum scandalo permanens, suspensione puniantur, cui persistente post monitionem delicto, aliae poenae gradatim addi possunt usque ad dimissionem e statu clericali.

$\$ 2$. Clericus qui aliter contra sextum Decalogi praeceptum deliquerit, si quidem delictum vi vel minis vel publice vel cum minore infra aetatem sedecim annorum patratum sit, iustis poenis puniatur, non exclusa, si casus ferat, dimissione e statu clericali.

W przekładzie polskim (za: Kodeks Prawa Kanonicznego. Przekład polski zatwierdzony przez Konferencję Episkopatu, Poznań 1984, s. 545, 547):

Kan. 1395 - \$1. Duchowny konkubinariusz poza wypadkiem, o którym w kan. 1394, oraz duchowny trwający w innym grzechu zewnętrznym przeciwko szóstemu przykazaniu Dekalogu, wywołującym zgorszenie, winien być ukarany suspensą, do której, gdy mimo upomnienia trwa w przestępstwie, można stopniowo dodawać inne kary, aż do wydalenia ze stanu duchownego.

$\$ 2$. Duchowny, który w inny sposób wykroczył przeciwko szóstemu przykazaniu Dekalogu, jeśli jest to połączone z użyciem przymusu lub gróźb, albo publicznie lub $\mathrm{z}$ osobą małoletnią poniżej lat szesnastu, powinien być ukarany sprawiedliwymi karami, nie wyłączając w razie potrzeby wydalenia ze stanu duchownego.

${ }^{6}$ Tytuł V części II Księgi VI Kodeksu Prawa Kanonicznego z 1983 r. (dalej w skrócie: CIC) stanowi wszak: „De delictis contra speciales obligationes”. Problem nie dotyczy kodeksu wschodniego z 1990 r., który nie zna dalszego podziału rozdziału II („Kary za poszczególne przestępstwa”) w Tytule XXVII („Sankcje karne w Kościele”). 
$\left.\mathrm{CCEO}^{7}\right)^{8}$. Wydaje się jednak, zwłaszcza w świetle poniższych uwag odnośnie do znamienia sprawcy ${ }^{9}$, że rozszerzanie zakresu tego znamienia na nie-duchownych wyraźnie wskazuje na przesuwanie akcentu z celibatu kościelnego na obyczajnośćc ${ }^{10}$.

Być może jednak rozejście się przedmiotu ochrony w kodeksie z 1983 r. i w normach o delicta graviora z 2010 r. bierze swój początek z niezharmonizowania ustawy o Kurii Rzymskiej z kodeksem łacińskim z 1983 r. Przepis art. 52 tejże ustawy stanowi bowiem wyraźnie o delicta contra mores ${ }^{11}$, podobnie zresztą jak art. 6 SST/2010.

${ }^{7}$ Skrót CCEO oznacza Codex Canonum Ecclesiarum Orientalium (Kodeks Kano-
nów Kościołów Wschodnich) z 1990 r. Przekład polski: Kodeks Kanonów Kościołów
Wschodnich, tłumaczenie L. Adamowicz, M. Dyjakowska, Lublin 2002 .
${ }^{8}$ Zgorszenie bowiem jest tym większe; por. C. DezuTTo, Le principali obiezioni
alla prassi della Congregazione per la Dottrina della Fede nel trattamento dei delicta
graviora ad essa riservati, w: I delitti riservati alla Congregazione per la Dottrina
della Fede: norme, prassi, obiezioni, red. C. Papale, Città del Vaticano 2015, s. 100.
${ }^{9}$ Zob. niżej, I.1.
${ }^{10}$ W przestępstwie indywidualnym, o czym niżej (por. I.1.1.), chodzi przede wszyst-
kim o ochronę celibatu jako obowiązku duchownych, a nie o ochronę zdrowia
i psychiki ofiar. Inaczej bowiem nie da się wyjaśnić braku penalizacji czynów doko-
nywanych przeciwko małoletnim przez świeckich; por. N. LüDICKE, Le violenze di
preti su minori nel diritto canonico, Il Regno - Documenti 55 (2010), s. 476 z przyp. 68. Zatem zmiana dokonywana w ustawodawstwie partykularnym wskazuje na przeciwną tendencję.

${ }^{11}$ Przepis ów stanowi: „Delicta contra fidem necnon graviora delicta tum contra mores tum in sacramentorum celebratione commissa, quæ ipsi delata fuerint, cognoscit atque, ubi opus fuerit, ad canonicas sanctiones declarandas aut irrogandas ad normam iuris, sive communis sive proprii, procedit" [IoAnnes PAUlus PP. II, Constitutio Apostolica Pastor bonus de Romana Curia, 28.06.1988, AAS 80 (1988) 841-912, art. 52; kursywa - P.S.]. W przekładzie polskim: “[Kongregacja Doktryny Wiary] rozpatruje powierzone jej przestępstwa przeciwko wierze oraz cięższe przestepstwa, tak przeciw obyczajom, jak i w sprawowaniu sakramentów, a także jeżeli to konieczne, deklaruje albo wymierza sankcje kanoniczne zgodnie z przepisami prawa czy to powszechnego, czy partykularnego" (przekład i kursywa - P.S.). Należy zauważyć, że dosłowne tłumaczenie nazwy Kongregacji powinno oddawać jej oddanie w służbie Biskupowi Rzymskiemu w jakiejś dziedzinie na sposób ciągły, co oddaje łaciński przyimek pro (czyli: Kongregacja dla Doktryny Wiary). 
Niestety, problemu zdaje się nie dostrzegać projektodawca zmian do nowej Księgi VI CIC, nie przewidując zmian w zatytułowaniu tytułu V, choć zmiany takie przewiduje w poprzedzających tytułach ${ }^{12}$, a nawet rozszerza penalizację czynu na sprawców nie-duchownych ${ }^{13}$. Jest to zupełnie nielogiczne, gdyż inni wierni nie mają „specjalnych obowiązków” w Kościele, jak duchowni. Ta uwaga krytyczna dotyczy również przestępstwa z kan. $1394 \mathrm{CIC}$, rozszerzonego w projekcie na świeckich i nie-zakonników ${ }^{14}$.

Stąd tym bardziej - de lege ferenda - zatytułowanie tytułu V w nowej Księdze VI powinno ulec zmianie. Proponuje się dodanie słów: ac (bonos) mores - na wzór CIC/17. Zatem nowe zatytułowanie tytułu V by brzmiało: „De delictis contra speciales obligationes ac (bonos) mores".

Przedmiotem niniejszego komentarza są więc delicta graviora contra mores, czyli art. 6 SST/2010. Artykuł ten stanowi: ${ }^{15}$

Art. $6-\S 1$. Delicta graviora conArt. $6-\$ 1$. Przestępstwami tra mores, Congregationi pro cięższymi przeciwko obyczajom, Doctrina Fidei cognoscendo reser- zarezerwowanymi do rozpoznania vata, sunt:

$1^{\circ}$ delictum contra sextum DeKongregacji Doktryny Wiary, są:

$1^{\circ}$ przestępstwo przeciwko szócalogi praeceptum cum minore in- stemu przykazaniu Dekalogu, fra aetatem duodeviginti annorum popełnione przez duchownego a clerico commissum; in hoc nu- z małoletnim poniżej 18. roku życia; mero minori aequiparatur persona w tym numerze z małoletnim zrówquae imperfecto rationis usu habitu nana jest osoba, która jest trwale pollet; ograniczona w używaniu rozumu;

\footnotetext{
12 Zob. Pontificium Consilium de Legum Textibus, Schema recognitionis Libri VI Codicis Iuris Canonici (Reservatum), Città del Vaticano 2011, s. 31-38.

${ }^{13}$ Por. tamże, s. 38, kan. $1395 \$ 4$.

${ }^{14}$ Zob. tamże, s. 37-38, kan. $1394 \$ 3$.

15 Tłumaczenie w tekście - P.S. Inne, oficjalne w: „L'Osservatore Romano”, wydanie polskie, 10 (2010), s. 53-56, a ponadto na stronie watykańskiej: http://www.vatican. va/resources/resources_norme_pl.html (2016.09.27).
} 
$2^{\circ}$ comparatio vel detentio vel divulgatio imaginum pornographicarum minorum infra aetatem quattuordecim annorum quovis modo et quolibet instrumento a clerico turpe patrata.

$\$$ 2. Clericus qui delicta de quibus in $\$ 1$ patraverit, pro gravitate criminis puniatur, non exclusa dimissione vel depositione. $2^{\circ}$ nabywanie lub przechowywanie, lub rozpowszechnianie obrazów pornograficznych małoletnich poniżej 14 lat życia w jakikolwiek sposób i za pomocą jakiegokolwiek narzędzia, dokonane przez duchownego w celu lubieżnym.

$\$ 2$. Duchowny, który popełnił przestępstwa $\mathrm{z} \$ 1$, ma być ukarany zgodnie z ciężkością występku, nie wyłączając wydalenia [ze stanu duchownego] lub depozycji.

W praktyce Kongregacji Doktryny Wiary w latach 2004-2013 zgłoszono 3.420 „wiarygodnych zarzutów” wobec duchownych o popełnienie komentowanego przestępstwa. W tym okresie 848 duchownych zostało przeniesionych do stanu świeckiego, a 2.572 kapłanów obłożono innymi karami. Od 1950 r. Kościoły partykularne i instytuty życia konsekrowanego na całym świecie wypłaciły ofiarom pedofilii odszkodowania na sumę 2,5 mld dolarów, a ponadto $78 \mathrm{mln}$ dolarów przeznaczono na pomoc terapeutyczną dla ofiar ${ }^{16}$. Jednak przypadki pedofilii sensu stricto stanowią jedynie $10 \%$ tej liczby, tj. mniej niż 0,07\% ogólnej liczby duchowieństwa na świecie ${ }^{17}$.Zjawisko to ponadto, na szczęście, podlega wyraźnemu osłabieniu $^{18}$.

\footnotetext{
${ }^{16}$ Dokładnie zaś w poszczególnych latach: w 2004 - 713, w 2005 - 184, w 2006 - 218, w 2007 - 216, w 2008 - 191, w 2009 - 196, w 2010 - 464, w 2011 - 402, w 2012 - 418 i w 2013 - 401 przypadki. Dane ujawnione przez abp. Silvano Tomasiego, watykańskiego obserwatora przy genewskich agendach ONZ, podane w 2014 r. podczas sesji Komitetu Przeciw Torturom; informacja za KAI: Liczba przypadków pedofilii [notatka prasowa KAI, bez wskazania autora], http://ekai.pl/wydarzenia/temat_dnia/ x78273/liczba-przypadkow-pedofilii/ (2014-05-07).

${ }^{17}$ Dane statystyczne podane przez ks. Charlesa Sciclunę w 2013 r.; por. G. CARDinali, Ch. Scicluna, Intervista di Gianni Cardinali a mons. Charles Scicluna sulla rigorosità della Chiesa nei casi di pedofilia, http://www.vatican.va/resources/ resources_mons-scicluna-2010_it.html (2016-12-17); P. BIELIŃsKi, Kościół nie jest bierny $w$ sprawie pedofilii, http://info.wiara.pl/doc/1720402.Kosciol-nie-jest-bierny-ws-pedofilii (2013-09-27).

${ }^{18}$ W latach 2007-2009 średnia oskarżeń zgłaszanych rocznie do Kongregacji wynosiła około 250, z czego aż 223 (w 2009 r.) z samych Stanów Zjednoczonych Ameryki
} 
Niezależnie od tych optymistycznie rokujących danych statystycznych trzeba przypomnieć słowa Benedykta XVI jako papieża emeryta z jego listu z dnia 20 sierpnia 2013 r. do prof. Piergiorgio Odifreddiego, ateisty ${ }^{19}$ : „Cierpieniem jest dla nas fakt, że siła zła przenika aż do tego stopnia wewnętrzny świat wiary. Z jednej strony musimy to cierpienie znosić, natomiast z drugiej musimy uczynić wszystko, co możliwe, aby takie przypadki nie miały więcej miejsca. Nie można się też pocieszać, że według badań socjologów odsetek księży winnych takich przestępstw nie jest wyższy od tego, jaki odnotowuje się w innych, porównywalnych kategoriach zawodowych. W każdym razie nie należy przedstawiać ostentacyjnie tej dewiacji, jakby była podłością typową dla katolicyzmu".

Stąd nadal trzeba doskonalić regulacje kościelne dotyczące nadużyć seksualnych wobec małoletnich. Taki jest też cel niniejszego komentarza, zwłaszcza jego uwag de lege ferenda.

Przestępstwo przeciwko szóstemu przykazaniu Dekalogu z małoletnim jest zatem komentowane według znamion ogólnych każdego przestępstwa kanonicznego. Najpierw są przedstawione znamiona przedmiotowe, $\mathrm{tj}$. znamię sprawcy i znamiona czasownikowe (opis

Północnej, z tym że w tym samym 2009 r. w całych Stanach Zjednoczonych Kościoła katolickiego dotyczyło jedynie 6 wiarygodnych zgłoszeń (cytując George’a Weigela w „First Things” z 29 marca 2010 r.). Wiele krajów zgłasza jeden lub dwa przypadki, np. Polska. Według raportu Kongresu USA Kościoła katolickiego dotyczy 0,03\% przypadków pedofilii w tym kraju, Niemiec - 0,04\%; por. tamże.

Według informacji o. Adama Żaka SJ, koordynatora Episkopatu Polski ds. ochrony dzieci i młodzieży i dyrektora Centrum Ochrony Dziecka w Krakowie, w Polsce od 2010 do 2013 r. co najmniej 19 księży zostało skazanych przez sądy powszechne za czynności seksualne z małoletnimi. Według innych danych o charakterze szacunkowym w Polsce w latach 2001-2011 zapadło 27 wyroków, w których księżom udowodniono nadużycia seksualne na szkodę małoletnich. Por. Statystyki przypadków czynów pedofilnych [notatka prasowa KAI, bez wskazania autora], http://www.deon.pl/religia/kosciol-i-swiat/z-zycia-kosciola/art,19106,statyki-przypadkow-czynow-pedofilnych.html (2014-06-26).

${ }_{19}$ Zob. Benedetto XVI papa emerito, Lettera Anzitutto devo a Piergiorgio Odifreddi, 20.08.2013, http://www.kath.net/news/43824 (2016-12-17), n. IV,1. Przekład polski fragmentu z włoskiego za: P. BIElıŃsKi, Kościół..., tamże. 
czynu i jego okoliczności modalne), następnie znamię podmiotowe (zawienienie czynu), a w końcu tzw. znamię legalne, czyli przewidziana kara, ewentualnie kwestia karalności przestępstwa. Bogata historia ${ }^{20}$ wraz $\mathrm{z}$ teologią tego przepisu w ustawodawstwie karnym Kościoła została pominięta, podobnie jak i kwestie proceduralne.

\section{ZNAMIONA PRZEDMIOTOWE}

\section{I.1. Znamię sprawcy, czyli przestępstwo indywidualne}

\section{I.1.1. Tylko duchowny (przestępstwa indywidualne)}

Tak przestępstwo przeciwko szóstemu przykazaniu Dekalogu z małoletnim poniżej 18. roku życia z n. 1 art. $6 \$ 1$ SST/2010, jak i przestępstwo pornografii małoletnich do 14. roku życia z n. 2 tegoż przepisu - mogą być popełnione jedynie przez duchownego (a clerico). Ustawodawca kościelny podkreśla to znamię sprawcy wielokrotnie. Również w $\$ 2$ art. 6 SST/2010 przypomina, że przestępstwa te może popełnić tylko duchowny, czyli taki wierny, który przyjął święcenia przynajmniej w stopniu diakonatu (por. kan. $266 \$ 1$ CIC in princ., kan. 358 CCEO).

Lege non distinguente, nie ma znaczenia inkardynacja takiego duchownego, w szczególności że jest on duchownym zakonnym, a także to, czy należy do obrządku łacińskiego czy wschodniego ${ }^{21}$. Z wyraźnego postanowienia ustawy, tj. art. $1 \$ 2$ SST/2010, wiadomo, że z jej zakresu podmiotowego nie wyłącza się kardynałów, patriarchów, legatów Biskupa Rzymskiego i biskupów (por. kan. $1405 \$ 3$ CIC, kan. 1061 CCEO) ${ }^{22}$.

\footnotetext{
${ }^{20}$ Por. N.P. CAFARDi, Before Dallas - The Original Response of the American Bishops to the Clergy's Sexual Abuse of Minors: An Historical Synopsis and Canonical Analysis, Romae 2006; N. LüDICKE, Le violenze..., s. 470-472, 476-478 (z odesłaniem do literatury).

${ }^{21}$ Por. F.R. Aznar GiL, El delito contra el sexto mandamiento del decálogo cometido por un clérigo con un menor de edad, Revista Español de Derecho Canónico 70 (2013), s. 491.

${ }^{22}$ Zob. J. BernAL, Cuestiones canónicas sobre los delitos más graves contra el sexto mandamiento del Decálogo, Ius Canonicum 54 (2014), s.171-172.
} 
Komentowane przestępstwa zatem są tzw. przestępstwami indywidualnymi (delicta propria), jak określa je doktryna prawa karnego, także kanonicznego ${ }^{23}$. Są to przestępstwa, które mogą być popełnione jedynie przez sprawcę albo posiadającego pewne określone cechy (np. bycie duchownym, jak w omawianym przestępstwie), albo znajdującego się w pewnej określonej sytuacji (np. tłumacza spowiedzi w kan. $1388 \$ 2$ CIC). Nie są to więc tzw. przestępstwa powszechne (delicta communia) - przestępstwa, które mogą być zrealizowane przez kogokolwiek, niezależnie od szczególnych charakterystyk sprawcy.

\section{I.1.2. Problem sprawstwa innych wiernych}

\section{I.1.2.1. Tradycja kanoniczna}

Postanowienie, że przestępstwa contra mores są przestępstwami indywidualnymi - to wyraźna zmiana stanu prawnego w stosunku do całej tradycji kanonicznej, a zwłaszcza do kodeksu z 1917 r. ${ }^{24}$. Kodeks poprzedni nie przewidywał, że sprawcami przestępstwa przeciwko szóstemu przykazaniu Dekalogu z małoletnim poniżej 16. roku życia może być świecki (laicus; por. kan. 2357 \$1 CIC/17). Zgodnie bowiem z postanowieniami kodeksu pio-benedyktyńskiego szersze było pojęcie duchownego. Pojęcie to obejmowało także tzw. minorystów, czyli przyjmujących święcenia niższe już od tonsury (por. kan. 108 $\$ 1$ CIC/17). Tak minoryści (por. kan. 2358 CIC/17), jak i majoryści

\footnotetext{
${ }^{23}$ Por. D. Cito, Las nuevas normas sobre los «delicta graviora», Ius Canonicum 50 (2010), s. 651-652; C. PAPALE, I delitti contro la morale, w: I delitti riservati alla Congregazione per la Dottrina della Fede, red. A. D’Auria, C. Papale, Città del Vaticano 2014, s. 29.

${ }^{24}$ Zob. J.S. Grabowski, Clerical Sexual Misconduct and Early Traditions Regarding the Sixth Commandment, The Jurist 55 (1995), s. 527-591; J.H. Provost, Offenses Against the Sixth Commandment: Toward a Canonical Interpretation of Canon 1395, The Jurist 55 (1995), s. 643; W. ReEs, Sexueller Missbrauch von Minderjährigen durch Kleriker. Anmerkungen aus kirchenrechtlicher Sicht, Archiv für katholisches Kirchenrecht 172 (2003), s. 398; J. TuOHEY, The Correct Interpretation of Canon 1395: The Use of the Sixth Cammandment in the Moral Tradition from Trent to the Present Day, The Jurist 55 (1995), s. 592-631.
} 
(por. kan. $2359 \$ 2 \mathrm{CIC/17)}$ byli karani za przestępstwo przeciwko szóstemu przykazaniu Dekalogu z małoletnim poniżej 16. roku życia.

\section{I.1.2.2. Obowiązujący stan prawny}

Zawężenie znamienia podmiotowego w ustawodawstwie obecnie obowiązującym jest jego poważnym brakiem ${ }^{25}$. Co więcej, brakiem, który nie znajduje mocnego uzasadnienia. Nie ma bowiem jakiegoś poważnego powiązania między celibatem kościelnym a częstotliwością popełniania przestępstw pedofilskich ${ }^{26}$, żeby sprawcą tego przestępstwa mógł być tylko duchowny. Ponadto w praktyce Kongregacji Doktryny Wiary zdarzają się przypadki takich czynów, których dopuścił się sprawca jeszcze jako świecki, a następnie został wyświęcony i stał się duchownym. W sensie ścisłym zastosowanie art. $6 \$ 1$ n. 1 SST/2010 nie jest możliwe, skoro przepisy prawa karnego mają być poddawane ścisłej wykładni (por. kan. 18 CIC, kan. 1500 CCEO).

Podobnie w sensie kanonicznym nie popełnia przestępstwa contra mores nadzwyczajny szafarz Komunii św., kiedy dokonuje czynności lubieżnej z małoletnim ${ }^{27}$. Państwowe organa ścigania będą reagowały na jego czyn, ale prawo karne kanoniczne nie uzna tego zachowania za przestępstwo kanoniczne (sic!). Oczywiście, nie oznacza to, że porządek kanoniczny w jakikolwiek sposób nie zareaguje (w drodze

\footnotetext{
${ }^{25}$ Już pod rządem kan. 1395 CIC ubolewano, że spod jego zakresu podmiotowego wyłączono zakonników; por. A. SÉRIAux, Droit canonique, Paris 1996, s. 730, nb. 293 d.

${ }^{26}$ Zob. E. Parolari, Aspetti psicopatologici dei delitti canonici, w: Questioni attuali di diritto penale canonico, Città del Vaticano 2012, s. 69. „Analiza przypadków wykorzystywania seksualnego pokazuje, że związek między pedofilią a celibatem jest mniejszy niż związek między pedoflią a zepsuciem środowiska rodzinnego" (J. Carola, M. Rotsaert, M. Tenace, H.M. YÁñez, Refleksje teologiczne i moralne dotyczące seksualnego wykorzystywania dzieci przez duchownych katolickich, w: Ku uzdrowieniu i odnowie. Materiały z sympozjum dla biskupów i przłożonych zakonnych o seksualnym wykorzystaniu osób niepełnoletnich. Papieski Uniwersytet Gregoriański 6-9 lutego 2012, przekł. z angielskiego Z. Kasprzyk, Kraków 2012, s. 173).

${ }^{27}$ Znany jest przypadek w Polsce 66-letniego kościelnego, który miał dopuszczać się „molestowania” 5 ministrantów poniżej 15. roku życia w Radomsku (por. http://www.tvn24.pl/lodz,69/prokuratura-koscielny-molestowal-ministrantow-co-najmniej-pieciu,608833.html, 2016-12-28).
} 
administracyjnej), gdyż tego typu czyn świeckiego, zaangażownego w posługę Kościoła, podważa wiarygodność misji Kościoła. Przeoczenie ustawodawcy kościelnego jest jednak poważne. Stąd w projekcie nowej Księgi VI CIC przewiduje się rozszerzenie znamienia sprawcy na świeckich ${ }^{28}$.

\section{I.1.2.3. Wytyczne KEP z 2014 r.}

Brak ów zauważyła Konferencja Episkopatu Polski w wytycznych dotyczących wstępnego dochodzenia kanonicznego w przypadku oskarżeń duchownych o czyny przeciwko szóstemu przykazaniu Dekalogu z osobą niepełnoletnią poniżej osiemnastego roku życia $\mathrm{z}$ dnia 7-8 października $2014 \mathrm{r}^{29}$ Zgodnie z normami polskimi znamię sprawcy komentowanego przestępstwa zostało rozciągnięte na osoby konsekrowane i ,innych świeckich, działających w strukturach Kościoła"30.

Zasadę, przyjętą w wytycznych Konferencji Episkopatu Polski, należy uznać za słuszną. Jednakże sposób, w jaki ów ustawodawca przyjął realizację tej zasady, poddać trzeba krytyce.

Przede wszystkim w prawie karnym nie można stosować ustawy karnej analogicznie ${ }^{31}$. Analogia jest zakazna w kan. 19 CIC $^{32}$. Z pew-

\footnotetext{
${ }^{28}$ Zob. Pontificium Consilium de Legum Textibus, Schema recognitionis Libri VI Codicis Iuris Canonici (Reservatum), Città del Vaticano 2011, s. 38, kan. $1395 \$ 4$.

${ }^{29}$ Por. Konferencja Episkopatu Polski, Wytyczne dotyczące wstępnego dochodzenia kanonicznego w przypadku oskarżeń duchownych o czyny przeciwko szóstemu przykazaniu Dekalogu z osobą niepełnoletnią poniżej osiemnastego roku życia, 7-8 października 2014 r., Akta Konferencji Episkopatu Polski (2015) nr 27, s. 39-49 [dalej w skrócie: Wytyczne KEP], n. 18. Wytyczne zostały znowelizowane uchwałą nr 5/376/2017 KEP z 6 czerwca 2017 r.

${ }^{30}$ „W sposób analogiczny, mutatis mutandis, należy postępować w przypadkach nadużyć przeciwko szóstemu przykazaniu z osobą niepełnoletnią poniżej osiemnastego roku życia popełnionych przez osoby konsekrowane lub innych świeckich, działających w strukturach Kościoła” (n. 18 Wytycznych KEP).

${ }^{31}$ „W sposób analogiczny, mutatis mutandis, należy postępować...” (n. 18 Wytycznych KEP in princ.).

${ }^{32}$ Por. H. Schmitz, Sexueller Mißbrauch durch Kleriker nach kanonischem Strafrecht, Archiv für katholisches Kirchenrecht 172 (2003), s. 385.
} 
nością ustawodawcy lokalnemu polskiemu chodziło o odpowiednie stosowanie tych przepisów. Ustawodawca zatem nie odróżnia stosowania odpowiedniego od analogicznego (sic!). Tymczasem wystarczyło odesłać do tych przepisów, rezygnując z ich "analogicznego" czy nawet „odpowiedniego” stosowania.

Ponadto nie jest zręczne sformułowanie „osoby konsekrowane i inni świeccy”. Skoro ustawdawca zdecydował się na taki przepis, to powinien mieć świadomość całej dyskusji wokół klasyfikacji osób konsekrowanych jako odrębnego (bądź nie) stanu w Kościele. Pozycja kanoniczna niektórych osób konsekrowanych to z pewnością świeckość (por. kan. 207 \$1 CIC). Stąd biorąc to kryterium z prawa Bożego za podstawę (chrzest i przyjęcie święceń), analizowane sformułowanie brzmiałoby tak: „osoby konsekrowane o pozycji świeckich i inni świeccy”. Należało zaś nawiązać do koncepcji trójstanowej Kościoła z kodeksu wschodniego (por. kan. $323 \$ 2$ CCEO) i po prostu określić zakres podmiotowy w ten sposób: „osoby konsekrowane i inni wierni”.

Poza tym zdumiewa posługiwanie się przez ustawodawcę lokalnego polskiego nieprawidłowym polskim językiem prawnym. W języku polskim odróżnia się nieletniego od małoletniego (sic!). Nieletni może być tylko sprawca przestępstwa (por. art. 10 k.k.), a ofiara przestępstwa jest tylko małoletnia (por. art. $41 \$ 1 \mathrm{la}$, art. 41a, art. 43c, art. 101 $\$ 4$ k.k. i inne). Co gorsza, ten błąd powtarzany jest w wielu przepisach Wytycznych KEP, a nawet znalazł się w jej tytule, choć wytyczne te nawiązują wprost do regulacji polskiego kodeksu karnego.

W końcu analizowane wytyczne w zaskakujący sposób zawężają zakres znamiona sprawcy do „świeckich, działających $w$ strukturach Kościoła”33. A co z takimi świeckimi, którzy nie działają „w strukturach" Kościoła, natomiast w imieniu Kościoła? Paradoksalnie, prawdopodobnie z niezręczności techniki legislacyjnej, pozostały one poza działaniem norm karnych (sic!), skoro przepisy karne należy wykładać ściśle (por. kan. 18 CIC, kan. 1500 CCEO). Tymczasem normy Konferencji Episkopatu Stanów Zjednoczonych Ameryki Północnej uniknęły tego błędu, wyraźnie przewidując odpowiedzialność kanonicznokarną

${ }^{33}$ Kursywa w n. 18 Wytycznych KEP - P.S. 
świeckich działających w imieniu Kościoła - czy to jako wolontariusze (anyone in church service ${ }^{34}$ ), czy też w inny sposób ${ }^{35}$ (na przykład „W strukturach” jako zatrudnieni: other church personnel ${ }^{36}$ ).

\section{I.1.3. Ciężkość kanoniczna przestępstwa a godność jego sprawcy}

Znamię sprawcy kieruje uwagę na wymiar kary, która przecież dotyka przestępcę jako osobę. Przy wymierzaniu kary trzeba mieć bowiem zawsze na względzie sprawcę przestępstwa. Nie chodzi tylko o jego właściwości i warunki osobiste. W sposób obiektywny karygodność i antykościelność przestępstwa wzrasta, kiedy dopuszcza się go biskup, a nie tylko diakon, choć obydwaj są duchownymi; piastujący jakiś urząd kościelny (np. proboszcza) czy też wierny, który żadnej funkcji w Kościele nie pełni ${ }^{37}$. Wśród okoliczności obciążających prawo karne kanoniczne wymienia właśnie godność (dignitas) sprawcy (por. kan. $1326 \$ 1$ n. 2 CIC).

\section{I.2. Znamię czasownikowe}

\section{I.2.1. Czynność wykonawcza przestępstwa}

\section{I.2.1.1. Szerokie rozumienie „przestępstwa przeciwko szóstemu przykazaniu Dekalogu"}

Ustawodawca kościelny opisał czyn zabroniony jako delictum contra sextum Decalogi praeceptum... commissum („popełnione...

\footnotetext{
${ }^{34}$ Zob. United States Conference of Catholic Bishops, Charter for the Protection of Children and Young People, 2011, http://www.usccb.org/issues-and-action/child-and-youth-protection/upload/Charter-for-the-Protection-of-Children-and-Young-People-revised-2011.pdf (2011-11-06), art. 1 alinea 1.

${ }^{35}$ Por. D.G. Astigueta, La persona..., s. 644.

${ }^{36}$ Zob. United States Conference of Catholic Bishops, Essential Norms for Diocesan/ Eparchial Policies Dealing with Allegations of Sexual Abuse of Minors by Priests or Deacons, 17.06.2005 (the revised edition 2011), http://www.usccb.org/ issues-and-action/child-and-youth-protection/upload/Charter-for-the-Protection-of-Children-and-Young-People-revised-2011.pdf (2011-11-06), n. 2.

${ }^{37}$ Por. H. Schmitz, Sexueller Miß3brauch..., s. 384.
} 
przestępstwo przeciwko szóstemu przykazaniu Dekalogu”) ${ }^{38}$. Brak jest zatem w tym opisie czynu zabronionego klasycznego znamienia czasownikowego, wskazującego dokładnie, o jakie czynności (czyli „czasowniki”) chodzi. Tak ogólne sformułowanie („popełnić przestępstwo") oznacza szerokie ujęcie czynu zabronionego. Chodzi bowiem o jakąkolwiek czynność zewnętrzną przeciwko szóstemu przykazaniu Dekalogu ${ }^{39}$. To zaś przykazanie w Tradycji Kościoła należy rozumieć nie tylko jako zdradę małżeńską, ale ogólnie jako ochronę ludzkiej seksualności ${ }^{40}$.

${ }^{38}$ Zresztą sformułowanie to było obecne w tym samym kontekście w kan. 2359 $\$ 2 \mathrm{CIC} / 17$.

${ }^{39}$ Taki też pogląd panuje bezspornie w całej literaturze przedmiotu; por. F.R. Aznar Gil, El delito..., s. 492-493; Tenże, Los „graviora delicta” reservados a la Congregación para la Doctrina de la Fe. Texto modificado (2010), Revista Española de Derecho Canónico 68 (2011), s. 300; D. BoREK, Delicta graviora contra mores $w$ Normach De delictis reservatis z 2010 roku, Prawo Kanoniczne 57 (2014) nr 2, s. 56; Tenże, Sextum Decalogi praeceptum..., s. 111; E. Gómez Martín, El delito..., s. 186, 189; J.P. Kimes, Considerazioni generali sulla riforma legislativa del motu proprio Sacramentorum Sanctitatis Tutela, w: I delicti riservati alla Congregazione per la Dottrina della Fede, red. A. D’Auria, C. Papale, Città del Vaticano 2014, s. 13; W. ReEs, Sexueller Missbrauch..., 402; H. Schmitz, Sexueller Missbrauch..., s. 387-388. Niekiedy wprost pisze się, że wyjątkowej pojemności (a catchall) tak sformułowanego znamienia czasownikowego przestępstwa; por. J.S. GRABOwsKi, Clerical Sexual Misconduct..., s. 529. Zresztą, objęcie przestępstw seksualnych popełnianych przez duchownych tym przykazaniem nie jest dawną tradycją Kościoła; zob. tamże, s. 529. Zwraca się także uwagę na kontekst tego wyrażenia, by móc go odpowiednio zinterpretować. W tym kontekście należy je rozumieć szeroko; por. J.H. Provost, Offenses..., s. 644. Dlatego Św. Oficjum pod rządem kan. $2359 \$ 2$ CIC/17 zrezygnowało z kodeksowego opisu przestępstwa na rzecz crimen pessimum jako „ciężkiego grzechu seksualnego zewnętrznego popełnionego lub usiłowanego z dzieckiem przed osiągnięciem dojrzałości seksualnej” (\$73-za: J.P. BEAL, The 1962 Instruction "Crimen sollicitationis”: Caught Red-Handed or Handed a Red Herring, Studia canonica 41 [2007], s. 206); por. J.H. Provost, Offenses..., s. 648-649.

${ }^{40}$ Zob. Katechizm Kościoła Katolickiego, n. 2336; E. Miragoli, Il confessore e il „de sexto". Prospettiva giuridica, Quaderni di diritto ecclesiale 4 (1991), s. 239 (wskazując na dwa znaczenia VI przykazania Dekalogu - skrypturystyczne i tradycyjnego nauczania Kościoła, czyli katechetyczne); K. LüDICKe, Komentarz do kan. 1395, w: Münsterischer Kommentar zum Codex Iuris Canonici, red. K. Lüdicke, Essen 
W ten sposób ustawodawca kościelny nawiązuje do fundamentu teologicznego prawa kanonicznego. Przede wszystkim jednak daje do zrozumienia, że grzech ciężki, bez którego nie może być mowy o przestępstwie kanonicznym (por. kan. $1321 \$ 1 \mathrm{CIC}$ ), determinuje znamię czasownikowe komentowanego przestępstwa ${ }^{41}$. Wiadomo zaś w teologii moralnej, że każdy wystąpek w materii czystości („szóste przykazanie Dekalogu”) ma charakter grzechu ciężkiego.

Jak bardzo szeroko jest rozumiane „przestępstwo przeciwko szóstemu przykazaniu Dekalogu”, wystarczy wspomnieć, że nie chodzi tylko o stosunki (homo- czy hetero-) seksualne. Znamię to zostało wypełnione, jeśli doszło do czynności lubieżnej w obecności drugiej osoby, np. masturbacji, dotykania intymnych części ciała, niekoniecznie organów płciowych, pieszczot w kontekście nieczystym, rozebrania się, ukazywania materiału pornograficznego czy wręcz tylko lubieżnego pocałunku ${ }^{42}$. Charakter przestępny w prawie kanonicznym będą ponadto miały: nieodpowiednie podarunki (np. bielizny

1984-, Stand: November 2001, 1395/3, nb. 4; J. TuOHEY, The Correct Interpretation..., s. $593,628-631,657-658$.

${ }^{41} \mathrm{~W}$ literaturze zaproponowano rozróżnienie „Zachowania grzesznego” (comportamenti peccaminosi) od „przestępczego” (delittuosi); por. B.F. PIGHIN, Diritto Penale Canonico, Venezia 2008, s. 481. Nie wydaje się jednak, by to rozróżnienie mogło mieć miejsce w przypadku komentowanego przestępstwa. W szczególności zaś podawane przykłady (powtarzane pocałunki wyrażające zamiar lubieżny, prowadzenie rozmów o charakterze seksulanym) wyczerpują znamiona przestępstwa. Co prawda można uznać, że w tym wypadku naruszenie ustawy karnej nie zostało dokonane graviter (por. $1321 \$ 1 \mathrm{CIC}$ ), czyli czyn nie ma wymaganej cieżkości kanonicznej i antykościelności. Zatem może nie dojść do wszczęcia postępowania karnego (por. kan. 1341 CIC).

${ }^{42}$ Por. A. Calabrese, Diritto Penale Canonico, Città del Vaticano 2006, s. 336; D. Cito, Norme „de gravioribus delictis”, w: Norme procedurali canoniche commentate, red. M. del Pozzo, J. Llobell, J. Miñambres, Roma 2013, s. 640; P. MAJER, Prawnokanoniczna ochrona dziecka przed nadużyciami seksualnymi, w: Prawa dziecka: perspektywa Kościoła, red. P. Kroczek, Kraków 2015, s. 110; M. Mosconi, Komentarz do kan. 1395, w: Codice di Diritto Canonico commentato, red. Redazione di Quaderni di diritto ecclesiale, Milano 2009, s. 1106; C. PAPALE, I delitti contro la morale..., s. 31; Z. Suchecki, La tutela penale dei minori presso la Congregazione per la Dottrina della Fede riguardo ai delicta graviora, Apollinaris 79 (2006), s. 723. 
intymnej), doprowadzanie do rozmów o charakterze seksualnym (też za pomocą telefonu czy czatu), opowiadanie o własnych doświadczeniach seksualnych ${ }^{43}$.

Co więcej, do grzechu ciężkiego w materii czystości (a zatem także do „przestępstwo przeciwko szóstemu przykazaniu Dekalogu” w myśl art. $6 \$ 1$ n. 1 SST/2010) dojdzie również, jeżeli ta obecność drugiej osoby nie będzie fizyczna, a jedynie telematyczna (np. za pomocą czatu, kamery wideo czy webcam, skype'a czy innych komunikatorów elektronicznych przekazujących dźwięk lub obraz) ${ }^{44}$. Wystarczy też samo nęcenie małoletniego w celu lubieżnym na przykład na czacie, przy pomocy telefonu komórkowego, facebooka czy w inny sposób - w sieci internetowej lub w „realu” (tzw. grooming, już karalny w niektórych państwowych ustawodawstwach karnych) ${ }^{45}$. Sam SMS o treści erotycznej do małoletniego już wyczerpuje znamiona przestępstwa $\mathrm{z}$ art. $6 \$ 1 \mathrm{n} .1 \mathrm{SST} / 2010^{46}$. Komentowane przestępstwo kanoniczne obejmuje bowiem wszystkie formy werbalne i niewerbalne, cielesne, zwłaszcza seksualne, naruszające godność małoletniego ${ }^{47}$.

${ }^{43}$ Zob. D.G. Astigueta, La persona e i suoi diritti nelle norme sugli abusi sessuali, Periodica de re canonica 93 (2004), s. 630-632; E. Gómez Martín, El delito..., s. 190; P. Majer, Prawnokanoniczna ochrona..., s. 110. Wszystkie zachowania, wskazywane w seksuologicznej i psychologicznej literaturze przedmiotu jako wykorzystywanie seksualne dzieci [por. M. Mozgawa, M. Budyn-Kulik, Prawnokarne aspekty pedofilii. Analiza dogmatyczna i wyniki badań empirycznych, Czasopismo Prawa Karnego i Nauk Penalnych 10 (2006) nr 2, s. 49-50], podpadają pod znamię kanoniczne popełnienia grzechu przeciwko szóstemu przykazaniu Dekaologu z małoletnim.

${ }^{44}$ Por. P. Majer, Prawnokanoniczna ochrona..., s. 110; C. PAPAle, I delitti contro la morale..., s. 32; Z. Suchecki, La tutela..., s. 723.

${ }^{45}$ Por. P. MAJER, Prawnokanoniczna ochrona..., s. 110; C. PAPAle, I delitti contro la morale..., s. 32. O innych zachowaniach przestępnych w kontekście przestępstwa kanonicznego pornografii dziecięcej, zob. P. Skonieczny, Przestępstwo cięższe pornografii dziecięcej. Komentarz do art. $6 \$ 1$ n. 2 Sacramentorum sanctitatis tutela $z 2010$ r., przesłane do druku w „Prawie Kanonicznym”, II.2.1.1., III.2.2.

${ }^{46}$ Zob. C. Dezutto, Le principali obiezioni..., s. 97.

${ }^{47}$ Por. F.R. Aznar Gil, El delito..., s. 493; P. Majer, Prawnokanoniczna ochrona..., s. 110 . 
Ofiara tego przestępstwa ma być jednak skonkretyzowana. Chodzi o tego właśnie Jana Kowalskiego, który stał się ofiarą przestępstwa popełnionego przez księdza Adama Nowaka. Zachowanie przestępne sprawcy jest zatem ściśle określone (ad certam personam). Dlatego nie wydaje się, by znamiona komentowanego przestępstwa wyczerpywało popieranie pedofilii jako takiej (ad incertam personam $)^{48}$. Nie oznacza to wszakże bezkarności takiego zachowania w prawie karnym kanonicznym (por. kan. 1371, ewentualnie kan. 1399 CIC). Zwykle też popierający legalizację pedofilii sami są pedofilami ${ }^{49}$.

\subsubsection{Uwagi prawnoporównawcze}

Nie wchodząc w szczegóły, należy podkreślić, że tak szerokie określenie czynności wykonawczej przestępstwa w porządku kanonicznym znacznie poszerza czyny spenalizowane $e^{50}$. Ta penalizacja jest większa niż we współczesnych kodeksach karnych.

Przykładowo w polskim prawie karnym chodzi o: doprowadzenie małoletniego do obcowania płciowego lub do poddania się innej czynności seksualnej albo do wykonania takiej czynności (art. 199\$2 i 3 k.k. - małoletni; art. $200 \$ 1$ k.k. - małoletni poniżej lat 15); prezentowanie lub udostępnianie małoletniemu poniżej 15 lat materiałów pornograficznych lub przedmiotów mających taki charakter (art. 200

\footnotetext{
${ }^{48}$ Jest to rozróżnienie analogiczne do tego, jakie przeprowadza się w literaturze karnistycznej, też kanonicznej, co do podżegania (por. kan. 1328 CIC) i przestępstwa nawoływania publicznego do nieposłuszeństwa (por. kan. 1373 CIC). Por. P. Skonieczny, La compartecipazione nel delitto canonico: alla ricerca del concetto teorico, Romae 2015, s. 148-149.

${ }^{49}$ Przykładowo, kazus holenderski ojca Van B., salezjanina, który publicznie popierał pedofilię, działając w fundacji Martijn walczącej o legalizację pedofilii. Zresztą, ojciec Van B. został dwukrotnie skazany za obnażanie się przed małoletnimi. Por. A. RYвıŃsKa, Ksiądz: seks $z$ dorosłym nie szkodzi dziecku, http://www. rp.pl/artykul/662868_Ksiadz__seks_z_doroslym_nie_szkodzi_dziecku_.html (2011-05-24).

${ }^{50}$ Znamię ogólnie sformułowane „przestępstwa przeciwko szóstemu przykazaniu Dekalogu” zapewnia szeroką elastyczność (broad flexibility) w przeciwieństwie do znamion ściśle określonych (sprawcy i ofiary); por. J.A. AlEssandro, Removal from Clerical State for the Sexual Abuse of Minors, Studia canonica 47 (2013), s. 304-305.
} 
$\$ 3$ k.k.); prezentowanie małoletniemu poniżej lat 15 wykonania czynności seksualnej (art. $200 \$ 4$ k.k.); reklama lub promocja działalności polegającej na rozpowszechnianiu treści pornograficznych w sposób umożliwiający zapoznanie się z nimi małoletniemu poniżej lat 15 (art. $200 \$ 5$ k.k.); tzw. child grooming (art. 200a k.k.). Oczywiście, wszystkie te czyny są spenalizowane przez porządek kanoniczny.

Jednym słowem, każde przestępstwo z małoletnim według polskiego prawa karnego będzie również przestępstwem kanonicznym (delictum mixtum) ${ }^{51}$, ale nie każde przestępstwo kanoniczne $\mathrm{z}$ art. $6 \$ 1 \mathrm{n}$. 1 SST/2010 będzie penalizowane w polskim k.k. (na przykład lubieżny pocałunek małoletniego $)^{52}$.

Bardzo ogólne i odwołujące się do pojęć teologii moralnej ujęcie czynu zabronionego pozwala na uniknięcie trudności ustawodawstw świeckich, aby precyzyjnie opisać wszystkie czynności zabronione, co często nie jest możliwe ${ }^{53}$. Z drugiej strony jednak prawo karne kanoniczne nie „cieniuje” przypadków w opisie czynu zabronionego, jednakowo traktując - z formalnego punktu widzenia - tak stosunek seksualny z małoletnim, jak i jego pocałunek ${ }^{54}$. Wskutek tego działanie przełożonego kościelnego będzie musiało być bardziej roztropne, skoro dostaje on dużą władzę uznaniową. Niestety, często będzie to jedynie postulat życzeniowy, biorąc pod uwagę atmosferę wokół skandali pedofilskich.

\subsubsection{Przestępstwo okazjonalne, habitualne, trwałe?}

Komentowane przestępstwo może być dokonywane habitualnie, tj. sprawca może trwać w grzechach przeciwko szóstemu przykazaniu Dekalogu z małoletnim. Może jednak dojść do jednorazowego,

\footnotetext{
${ }^{51}$ Zob. P. Majer, Prawnokanoniczna ochrona..., s. 105-106.

${ }^{52}$ Stąd nie zawsze przestępstwo kanoniczne będzie pokrywało się z przestępstwem według prawa świeckiego i trzeba raczej mówić o „równoległym wymiarze sprawiedliwości” („justicia paralela”); por. E. Gómez Martín, El delito..., s. 186.

${ }^{53}$ Stąd propozycja de lege ferenda nowego brzmienia tego przepisu, obejmującego także pornografię dziecięcą; por. P. SKonieczny, Przestępstwo cięższe pornografii dziecięcej..., II.2.1.3.

${ }^{54}$ Tak też słusznie, por. C. Dezutto, Le principali obiezioni..., 97.
} 
okazjonalnego upadku w tym grzechu z małoletnim. To wszakże wystarcza, aby zostały wyczerpane znamiona omawianego typu czynu zabronionego ${ }^{55}$ - tak w myśl kan. $1395 \$ 2$ CIC, jak i art. 6 $\S 1$ n. 1 SST/2010.

Ta ostatnia uwaga jest o tyle istotna, że przestępstwo contra castitatem z kan. $1453 \$ 1$ CCEO może być jedynie trwałe (permanens), a zatem nigdy okazjonalne ${ }^{56}$. Dlatego art. $6 \$ 1 \mathrm{n}$. 1 SST/2010 poszerza znacznie karalność takich czynów contra castitatem z małoletnimi w odniesieniu do duchownych podlegających dyscyplinie prawa wschodniego.

\section{I.2.2. Podmiot wykonawczy przestępstwa, czyli ofiara}

\section{I.2.2.1. Uwagi ogólne i psychiatryczne}

Podmiotem wykonawczym komentowanego przestępstwa, czyli ofiarą, jest:

a) minor infra aetatem duodeviginti annorum („małoletni poniżej 18. roku życia");

b) persona quae imperfecto rationis usu habitu pollet („osoba, która jest trwale ograniczona w używaniu rozumu”).

Oczywiście, nie ma znaczenia płeć ofiary: może to być tak chłopiec, jak i dziewczyna ${ }^{57}$. Nie ma też znaczenia prawnego ewentualna zgoda ofiary na tę czynność wykonawczą, na przykład dziewczyna zakochana w duszpasterzu „zgadza się na wszystko”58.

\footnotetext{
${ }^{55}$ Por. A. Calabrese, Diritto Penale Canonico, Città del Vaticano 2006, s. 336, wskazując, że znaczenie to wynika ze spójnika vel (“lub”), użytego przez ustawodawcę kościelnego w w kan. 1395 \$ 2 CIC. Ponadto na przykład, por. P. Majer, Prawnokanoniczna ochrona..., s. 110.

${ }^{56}$ Inna uwaga odnośnie do przestępstwa z kan. $1453 \$ 1$ CCEO, zob. niżej, przyp. 67.

${ }^{57}$ Por. D. Borek, Sextum Decalogi praeceptum $w$ kanonicznym prawie karnym aktualnie obowiązującym, Tarnów 2015, s. 113; C. PAPALE, I delitti contro la morale..., s. 30 .

${ }^{58}$ Por. D. Borek, Sextum Decalogi praeceptum..., s. 112-113; C. Papale, I delitti contro la morale..., s. 30 .
} 
W tym miejscu należy wskazać na ujęcie medyczne pedofilii oraz wskazać na klasyfikacje tzw. chronofilii, związane z wiekiem ofiar komentowanego przestępstwa.

Pedofilia odnosi się do zwyczajnego pociągu seksualnego do dzieci przed pokwitaniem płciowym (do ok. 12-13 lat). Przedmiotem tej dewiacji jest zatem dziecko nie w znaczeniu metrykalnym czy prawnym, lecz według cech jego budowy somatycznej. Granicą zainteresowania seksualnego pedofila jest najczęściej pojawienie się u dziecka trzeciorzędowych cech płciowych, szczególnie owłosienia łonowego, dziecięca budowa ciała, charakterystyczne ruchy ciała, delikatność czy gładkość skóry ${ }^{59}$. W znaczeniu medycznym sprawca, dojrzały pod względem seksualnym (a zatem musi mieć 16 lat), jest starszy od ofiary o co najmniej 5 lat, a jego preferencja seksualna występuje od co najmniej 6 miesięcy (kod 302.2 DSM-IV; kod F65.4 ICD-10) ${ }^{60}$. Inne odróżnienia medyczne pedofilów nie mają znaczenia prawnego, choć mogą wpłynąć na wybór zastosowanej kary kanonicznej ${ }^{61}$.

\footnotetext{
${ }^{59}$ Por. P. Marcinek, A. KapaŁA, Pedofilia w opiniowaniu sądowo-seksuologicznym, „Seksuologia Polska” 10 (2012) nr 2, s. 77-78, on-line: https://journals.viamedica.pl/ seksuologia_polska/article/viewFile/33534/24577 (2016-12-19).

${ }^{60}$ Zob. I. Łucka, A. Dziemian, Pedofilia - przegląd literatury, ilustracja kazuistyczna, dylematy, Psychiatria Polska 48 (2014) nr 1, s. 122; on-line: http://strona. ppol.nazwa.pl/uploads/images/PP_1_2014/121\%C5\%81ucka_PsychiatrPol_1_2014. pdf (2016-12-05); M. RATAJCZAK, Czynności pedofilskie - ujęcie prawne i kryminologiczne, Prokuratura i Prawo (2014) nr 2, s. 47, on-line: http://www.ies.krakow.pl/ wydawnictwo/prokuratura/pdf/2014/02/3ratajczak.pdf (2016-12-19); M. MozGAwA, M. Budyn-Kulik, Prawnokarne aspekty..., s. 43-48. Natomiast według obowiązującego w Polsce ISD-10, czyli Międzynarodowej Klasyfikacji Chorób i Problemów Zdrowotnych (ICD-10, International Statistical Classification of Diseases) pedofilia to zaburzenie seksualne, czyli „preferencja seksualna osoby dorosłej w stosunku do dzieci, zwykle w wieku przedpokwitaniowym lub we wczesnym okresie pokwitania”; por. P. Marcinek, A. KapaŁa, Pedofilia..., s. 77-79.

Autor dziękuje za konsultacje z zakresu psychiatrii o. dr. Arturowi Hąci OP, lekarzowi medycyny, który jest w trakcie specjalizacji z psychiatrii.

${ }^{61}$ Chodzi przede wszystkim o typ fiksacyjny (właściwy) pedofila, który od najwcześniejszych lat za najatrakcyjniejszy obiekt seksualny uważa dzieci. Z kolei typ pedofila regresyjnego (zastępczego, sytuacyjnego) kieruje zainteresowania seksualne na dzieci tylko wtedy, gdy nie może (z różnych względów) zaspokoić popędu
} 
W ramach tzw. chronofilii wyróżnia się ponadto hebefilię i efebofilię. Hebefilia oznacza preferencję seksualną dorosłych do osób we wczesnym okresie dojrzewania, czyli ok. 11-14 lat. Efebofilia zaś jest preferencją seksualną dorosłych do osób w późnym okresie dojrzewania, tj. ok. 15-19 lat ${ }^{62}$. Wszystkie te rodzaje zaburzeń preferencji seksualnych są zwane parafiliami, jednak nie są w znaczeniu medycznym pedofilią.

Psychiatrię interesuje jedynie pedofilia w znaczeniu medycznym, a nie prawnym. Tylko bowiem taka oznacza zaburzenia w sferze seksualnej. Co więcej, medycyna często będzie się rozmijała $z$ ujęciem prawnym. Zdarza się bowiem, że przestępstwo z art. $6 \$ 1$ n. 1 SST/2010 popełni nie-pedofil w znaczeniu medycznym, na przykład kiedy jego preferencja seksualna nie występowała w chwili dokonania czynu od co najmniej 6 miesięcy ${ }^{63}$. W znaczeniu prawnym sprawca taki, choć

seksualnego z partnerem dorosłym. Można również wyróżnić - według innego kryterium - typy pedofila: infantylnego, cechującego się niedojrzałą osobowością, preferującego zabawy seksualne z dziećmi (dotykanie, przytulanie, głaskanie, całowanie); dewianta, którego pociąga jedynie seks z dziećmi i z którymi kontaktów poszukuje już w wieku dojrzewania, preferując kontakty oralno-genitalne; regresywnego, traktującego dziecko jak zastępczą osobę dorosłą, doprowadzającego do pełnych stosunków seksualnych; w końcu pedofila-sadystę, osiągającego pełną satysfakcję seksualną jedynie przez brutalny gwałt na dziecku. Wśród pedofili niekiedy się wyróżnia nepiofilów, mających zainteresowanie dziećmi w wieku przedszkolnym. Zob. I. Łucka, A. Dziemian, Pedofilia..., s. 122; M.C. Seto, The Puzzle of Male Chronophilias, Archives of Sexual Behavior 22.08.2016, s. 1-20, on-line: 10.1007/s10508-016-0799-y (2016.12.14).

${ }^{62}$ Przedstawienie złożności problemu nadużyć seksualnych z małoletnimi, zob. E. Gómez Martín, El delito contra el sexto mendamiento del Decálogo cometido por un religioso con un menor, Revista Español de Derecho Canónico 69 (2012), s. 166-172. Co do samego zagadnienia, por. P. СıмвоLIC, The identification and treatment of sexual disorders ad the priesthood, The Jurist 52 (1992), s. 600, 605-606. O stronie psychologicznej tego przestępstwa, wspominając jego pięć faz (porozumienie, relacja seksualna, nałożenie tajmenicy, ujawnienie, zaprzeczenie); por. E. Gómez MarTíN, El delito..., s. 179-180.

${ }^{63}$ Por. P. Marcinek, A. KapaŁa, Pedofilia..., s. 79. Ponadto pojedyncze wydarzenie, szczególnie gdy sprawca sam jest osobą w okresie dorastania, nie oznacza stałej czy przeważającej tendencji, uprawniającej do rozpoznania pedofilii w sensie 
nie jest pacjentem jako pedofil, to staje się przestępcą pedofilskiego czynu zabronionego ${ }^{64}$.

\section{I.2.2.2. Małoletni}

$\mathrm{W}$ miarę jasne jest znamię podmiotu wykonawczego przestępstwa z art. $6 \$ 1$ n. 1 SST/2010. Ustawodawca kościelny wyraźnie określa ofiarę jako każdego małoletniego (minor) zgodnie $\mathrm{z}$ jego definicją legalną z kan. $97 \$ 1$ CIC (kan. $909 \$ 1$ CCEO), pars secunda. Zatem małoletnim - również w rozumieniu obowiązujących przepisów kanonicznokarnych - jest każda osoba poniżej 18. roku życia.

Wiek osoby w prawie kanonicznym liczy się według przepisów o czasie ciągłym z kan. $201 \$ 1$ CIC (kan. $1544 \$ 1$ CCEO), tj. niedopuszczającym żadnej przerwy, a więc zgodnie z kalendarzem (por. kan. $202 \$ 2$ CIC; $1545 \$ 2$ CCEO) i po upływie dnia, w którym kończy się 18. rok życia (por. kan. $203 \$ 2$ CIC; $1546 \$ 2$ CCEO) ${ }^{65}$. Ta ostatnia uwaga jest o tyle istotna, że w prawie cywilnym polskim przy obliczaniu wieku osoby fizycznej termin upływa z początkiem, a nie z końcem (jak w prawie kanonicznym) ostatniego dnia ${ }^{66}$.

Nie wydaje się, by to podkreślenie było konieczne z punktu widzenia poprawności legislacyjnej, skoro wyraźną definicję małoletniego zawiera kodeks. Takie powtórzenie wszakże było podyktowane zmianą stanu prawnego, gdyż kan. $1395 \$ 2 \mathrm{CIC}^{67}$ (podobnie zresztą

medycznym; por. tamże, s. 79. Według badań na aktach sądowych w Polsce w 2012 r. na 106 skazanych osób jedynie w 8 przypadkach ujawniono nadużycia seksualne związane z dewiacją seksualną w postaci pedofilii; por. za: M. RATAJCzAK, Czynności pedofilskie..., s. 57 z przyp. 37.

${ }^{64}$ Zob. P. MAJER, Prawnokanoniczna ochrona..., s. 111-112.

${ }^{65}$ Por. R. Sobański, Komentarz do kan. 200-203, w: J. Krukowski, R. Sobański, Komentarz do Kodeksu Prawa Kanonicznego, t. I: Księga I. Normy ogólne, red. J. Krukowski, Poznań 2003, s. 293, 296.

${ }^{66}$ Zob. art. 112 kodeksu cywilnego, zdanie drugie, który stanowi: „Jednakże przy obliczaniu wieku osoby fizycznej termin upływa zpoczątkiem ostatniego dnia” (kursywa - P.S.).

${ }^{67}$ Kodeks wschodni natomiast nie zawiera natomiast przestępstwa analogicznego do ustawodawstwa łacińskiego. Inaczej, por. C. PAPALE, I delitti contro la morale..., s. 29, przyp. 1, uznając, że takim przestępstwem jest kan. $1453 \$ 1$ CCEO. 
jak poprzedni kan. $2357 \$ 1$ oraz kan. $2359 \$ 2$ CIC/17) określały jako małoletniego tylko osobę do 16. roku życia (minor infra aetatem sexdecim/sedecim annorum).

W tym miejscu należy wskazać różnice z ustawodawstwami państwowymi. Przykładowo polski kodeks karny uznaje za przestępstwo czynność seksualną z małoletnim poniżej lat 15 (por. art. $200 \mathrm{i}$ art. 200a k.k.), znając wszkaże także penalizację, ale tyko pewnych czynów z małoletnim w ogóle (czyli do lat 18 - art. 199 \$ 2 i 3 k.k. oraz art. $202 \$ 3-4 c$ i art. $204 \$ 3$ k.k.).

Porządek kanoniczny jest zatem bardzo surowy. Prawo karne kanoniczne na niespotykaną chyba w ustawodawstwach państwowych skalę podwyższa wiek ofiary aż do 18. roku życia. Dlatego komentowanego przestępstwa $\mathrm{z}$ art. $6 \$ 1 \mathrm{n} .1 \mathrm{SST} / 2010$ nie powinno się nazywać przestępstwem pedofilii. Pedofilia bowiem dotyczy jedynie małoletnich przed okresem pokwitani ${ }^{68}$. Tymczasem prawo karne kanoniczne wykracza z penalizacją poza klasyczne przestępstwo pedofilii, obejmując z pewnością także hebefilię oraz efebofilię ${ }^{69}$.

De lege ferenda należy się zastanowić, czy rozwiązanie przyjęte w porządku kanonicznym jest słuszne. Czy można - z punktu widzenia formalnego - jednakowo traktować sprawcę, którego ofiarą jest 5-letnie dziecko, oraz sprawcę, który dopuścił się czynności seksualnej z 17-latką, do tego wyjątkowo rozwiniętą? Co więcej, istnieje pewna sprzeczność w samym systemie prawa kanonicznego, który z jednej strony uznaje, że 14-latka jest dojrzała do podjęcia czynności seksualnych (poprzez jej zdolność do zawarcia małżeństwa kanonicznego por. kan. $1083 \$ 1$ CIC, $800 \$ 1$ CCEO), a z drugiej strony jakąkolwiek czynność $\mathrm{z}$ taką nastolatką $\mathrm{w}$ celu lubieżnym uznaje za przestępstwo. W końcu należy podkreślić, że nowe regulacje prawnokarne

\footnotetext{
Tego poglądu podzielić nie można, gdyż kan. $1453 \$ 1$ CCEO stanowi typ czynu zabronionego trwałego contra castitatem. Tymczasem przestępstwa z kan. $1395 \$ 2$ CIC oraz z art. $6 \$ 1$ n. 1 SST/2010 mogą być popełnione okazjonalnie.

${ }^{68}$ Por. wyżej, I.2.2.1.

${ }^{69}$ Tylko co do efebofilii, por. F.R. Aznar GiL, El delito..., s. 491-492; D. Borek, Sextum Decalogi praeceptum..., s. 113; C. PAPALE, I delitti contro la morale..., s. 30.
} 
Kościoła powstały pod wyraźnym wpływem skandali pedofilskich na Zachodzie, nie licząc się zupełnie $\mathrm{z}$ innym kontekstem kulturowym w innych regionach Kościoła powszechnego (np. w Afryce) ${ }^{70}$. Stąd zupełnie słuszne jest podejście filipińskiej konferencji episkopatu, która odróżnia w swojej ustawie partykularnej karnej pedofilię (nadużycia seksualne z małoletnimi do 13. roku życia) oraz efebofilię (z małoletnimi pomiędzy 13. a 18. rokiem życia $)^{71}$.

\section{I.2.2.3. Osoba trwale ograniczona w używaniu rozumu}

Ofiarą omawianego przestępstwa przeciwko szóstemu przykazaniu Dekalogu może być nie tylko małoletni. Począwszy od nowelizacji z 2010 r., ofiarą tą może być również osoba:

- trwale ograniczona w używaniu rozumu (persona quae imperfecto rationis usu habitu pollet - art. $6 \$ 1 \mathrm{n} .2$ SST/2010, pars secunda),

- która stała się już pełnoletnia, a zatem skończyła lat 18 (por. kan. $97 \$ 1$ CIC, pars prima), a ponadto

- nie korzysta ze zwykłej ochrony prawnej, przewidzianej w pierwszej części n. 1 art. $6 \$ 1$ SST/2010 ${ }^{72}$.

Komentowane postanowienie art. $6 \$ 1 \mathrm{n} .1 \mathrm{SST} / 2010$, pars secunda, nie jest li tylko teoretyczne, skoro duszpasterska misja Kościoła dotyczy również osób cierpiących. Może się zatem zdarzyć sprzeniewierzenie tej misji kapelanów (ale i pomocników duszpasterskich) w szpitalach dla psychicznie chorych, domach starców itd. Zresztą, nowelizacja Sanctitatis sacramentorum tutela w 2010 r. między innymi

\footnotetext{
${ }^{70}$ Por. C. Dezutto, Le principali obiezioni..., s. 96.

${ }^{71}$ Zob. D.G. Astigueta, La persona..., s. 636. Takie odróżnienie pomaga również w określeniu, jak poważny jest problem sprawcy; por. tamże, s. 637. Same normy jednak nie różnicują zagrożenia karą kanoniczną; por. CATHOLIC Bishops' ConfERenCe of The Philippines, Pastoral Guidelines on Sexual Abuses and Misconduct by the Clergy, 1.09.2003, http://www.cbcponline.net/v3/documents/2000s/2003-SEXUAL_ABUSES_AND_MISCONDUCT.htm (2016-11-06), $\$ 12$ ust. B.

${ }^{72}$ Por. F.R. AznAr GiL, El delito..., s. 494-495; F.R. Aznar Gil, Los „graviora delicta” reservados a la Congregación para la Doctrina de la Fe. Texto modificado (2010), Revista Española de Derecho Canónico 68 (2011), s. 300-301.
} 
była spowodowana tego typu nadużyciami, z którymi spotkała się w swej praktyce Kongregacja Doktryny Wiary.

Zwrócić należy uwagę, że chodzi o osobę ograniczoną (znamię „imperfecto") w używaniu rozumu, a nie tego rozumu pozbawioną (por. kan. 99 i kan. 1322 CIC, kan. $909 \$ 3$ CCEO) ${ }^{73}$. Jest ona w końcu zrównana z małoletnimi (do 18. roku życia), a nie z dziećmi (do 7. roku życia). Po skończonym 7. roku życia domniemywa się posiadanie używania rozumu (kan. $97 \$ 2$ CIC in fine; kan. $909 \$ 2$ CCEO, pars secunda), które przecież może być ograniczone.

Co więcej, ograniczenie używania rozumu jest trwałe (znamię „habitu”) ${ }^{74}$. Trwałość ta oznacza habitualność: osoba ta zwyczajnie, normalnie jest ograniczona w swoich władzach umysłowych. To znamię wyklucza dwie skrajności.

Po pierwsze, tak rozumiane znamię trwałości oznacza, że z ochrony prawnokarnej na podstawie art. $6 \$ 1$ n. 1 SST/2010, część druga, nie korzysta osoba przejściowo tylko zaburzona w swej zdolności do używania rozumu ${ }^{75}$, np. pod wpływem alkoholu. Może się zatem zdarzyć, że duchowny wykorzysta bezradność kobiety pełnoletniej, którą zmorzy sen po upojeniu alkoholowym, i doprowadzi ją do poddania się stosunkowi seksualnemu. O ile jest to przestępstwo z art. 198 k.k., o tyle w prawie karnym kanonicznym brakuje jego odpowiednika, gdyż art. $6 \$ 1$ n. 1 SST/2010, część druga, dotyczy jedynie trwałego, a nie przejściowego - jak w tym przykładzie - ograniczenia używania rozumu przez ofiarę przestępstwa duchownego. Taką podstawą prawną nie może też być kan. $1395 \$ 2$ CIC, gdyż nie ma miejsca żadna z okoliczności modalnych czynu, tj. ani przymus (vis), ani groźba

\footnotetext{
${ }^{73}$ Zob. V.G. Dhas, Modifiche introdotte nelle norme riguardanti i "graviora delicta”, Apollinaris 84 (2011), s. 360; C. PAPAle, I delitti contro la morale..., s. 30; J.L. SÁnchez-Girón Renedo, Delitos contemplados en las Normas de gravioribus del año 2010, Estudios Eclesiásticos 85 (2010), s. 764-765.

${ }^{74}$ Por. C. PApale, I delitti contro la morale..., s. 30.

${ }^{75}$ Por. tamże, s. 30; J.L. SÁnchez-Girón Renedo, Delitos contemplados en las Normas de gravioribus del año 2010, Estudios Eclesiásticos 85 (2010), s. 765.
} 
(minae). Stąd porządek kanoniczny musiałby przejść na kan. 1399 CIC jako podstawę reakcji prawnokarnej ${ }^{76}$.

Po drugie, znamię trwałości w takim rozumieniu nie oznacza permanentności czy stałości, która wyklucza okresy remisji. Remisja (tzw. lucida intervalla) może się zdarzyć. Pytanie, czy w takim okresie remisji ofiary duchowny, który z nią dopuszcza się grzechu przeciwko szóstemu przykazaniu Dekalogu, popełnia nadal przestępstwo cięższe $\mathrm{z}$ art. $6 \$ 1 \mathrm{n} .1$ SST/2010, część druga. Wydaje się, że tak, skoro taka osoba nadal jest trwale ograniczona w używaniu rozumu ${ }^{77}$.

Przyczyna tego trwałego ograniczenia w używaniu rozumu nie jest w jakikolwiek sposób zawężona przez ustawodawcę kościelnego w art. $6 \$ 1 \mathrm{n} .1 \mathrm{SST} / 2010$, część druga. Może ona mieć przyczynę $\mathrm{w}$ chorobie psychicznej lub upośledzeniu psychicznym, w demencji starczej, a w końcu w uzależnieniu alkoholowym czy narkotykowym, ale tylko takim, które powoduje trwałe ograniczenie zdolności intelektualnych ${ }^{78}$.

De lege ferenda należy podnieść, że ustawodawca kościelny nie jest konsekwenty w swoich regulacjach, a przynajmniej nie można się doszukać w nich jakiejś wyraźnej motywacji, która kierowała ustawodawcą. Czym bowiem różni się sytuacja ofiary przestępstwa, która jest ograniczona w używaniu rozumu trwale, od ofiary tak samo ograniczonej, tyle że przejściowo, czasowo? Sama karygodność czynu nie ulega przecież zmianie. Sprawca bowiem wykorzystał bezradność ofiary dla zaspokojenia swojego popędu seksualnego. To z tego powodu spotyka się z reakcją prawnokarną. To, czy ta bezradność ma

\footnotetext{
${ }^{76}$ Podobny przypadek opisywały media w Polsce w 2013 r. Duchowny miał pić alkohol z kobietą (pełnoletnią), a następnie wykorzystać ją seksualnie, kiedy ta spała (http://trojmiasto.gazeta.pl/trojmiasto/1,35636,14315224,Zakonnik_w_areszcie_ ma_zarzut_seksualnego_wykorzystania.html\#ixzz2ZiOVg952, 2013-07-21).

77 Taki też pogląd wyrażono w literaturze przedmiotu; por. J. BERnAL, Cuestiones canónicas..., s. 173; C. PAPALE, I delitti contro la morale..., s. 30-31.

${ }^{78}$ Por. C. PApale, I delitti contro la morale..., s. 31. Nie oznacza to jednak, że każdy alkoholik może być ofiarą komentowanego przestępstwa; por. J. BERNAL, Cuestiones canónicas sobre los delitos más graves contra el sexto mandamiento del Decálogo, „Ius Canonicum" 54 (2014), s. 174; D. Borek, Sextum Decalogi praeceptum..., s. 114-115.
} 
charakter trwały czy przejściowy, nie powinna mieć znaczenia. Tak właśnie tę kwestię uregulował ustawodawca polski w art. 198 k.k., kierując się wyraźnym określeniem dobra prawnie chronionego wolność seksualna. Takiej jasności zabrakło ustawodawcy kościelnemu i stąd nie do końca przemyślane i - jak się wydaje - pozbawione uzasadnienia znamię trwałości („habitu”) w art. $6 \$ 1$ n. 1 SST/2010, pars secunda. $\mathrm{Z}$ tego znamienia powinno się zatem de lege ferenda zrezygnować.

\section{I.2.3. Zbieg przestępstw}

W oparciu o orzecznictwo świeckie w literaturze wskazano, że możliwy jest zbieg przestępstw z art. $6 \$ 1 \mathrm{n}$. 1 SST/2010 oraz z kan. 1397 CIC (kan. 1451 CCEO). Chodzi o uprowadzenie i zatrzymanie człowieka (tu: małoletniego) tak, aby sprawca mógł popełnić grzech przeciwko szóstemu przykazaniu Dekalogu. Zazwyczaj uprowadzenie i zatrzymanie takiego małoletniego będzie współukarane (absorbowane) jako czynność uprzednia do przestępstwa z art. $6 \$ 1 \mathrm{n}$. 1 SST/2010. Jest to tzw. współukarany czyn uprzedni, tj. jeden czyn zabroniony jest środkiem do popełnienia innego czynu zabronionego o większej ciężkości kanonicznej. Jednakże może być i tak, że zatrzymanie małoletniego dokonało się dłużej, niż to było potrzebne do jego wykorzystania seksualnego; wówczas nastąpi realny zbieg przestępstw ${ }^{79}$.

Może dojść również do zbiegu idealnego (formalnego) przestępstw. Będzie on miał miejsce wówczas, gdy jednym czynem sprawca naruszy kilka typów czynów zabronionych, np. zgwałci małoletniego ${ }^{80}$. Nie tylko dopuści się bowiem przestępstwa z art. $6 \$ 1 \mathrm{n} .1$ SST/2010, część pierwsza, ale również przestępstwa zgwałcenia z kan. $1395 \$ 2$

\footnotetext{
${ }^{79}$ Por. C. Papale, I delitti contro la morale..., s. 33. Taki przypadek nie jest nierealny i zdarzył się w diecezji kieleckiej. Księdzu Adamowi W. zostały postawione zarzuty kilku zgwałceń tej samej nieletniej oraz pozbawienia jej wolności, do czego miało dojść w latach 2013-2014 (http://info.wiara.pl/doc/3021312.Jedrzejow-Ksiadz-oskarzony-o-pedofilie, 2016-03-12).

${ }^{80} \mathrm{Jak}$ w wyżej opisanym przypadku kieleckim.
} 
CIC. Może mieć wówczas zastosowanie kan. 1346 CIC dotyczący zbiegu przestępstw, lege non distinguente, realnego i idealnego ${ }^{81}$.

\section{ZNAMIONA PODMIOTOWE}

\section{II.1. Zamiar bezpośredni - czy tylko?}

\section{II.1.1. Cum dolo}

W literaturze podnosi się, że przestępstwo przeciwko szóstemu przykazaniu Dekalogu z małoletnim poniżej 18. roku życia z n. 1 art. $6 \$ 1 S S T / 2010$, jak i przestępstwo pornografii z małoletnimi do 14 lat, opisane w n. 2 tegoż artykułu, mogą być popełnione tylko z zamiarem bezpośrednim (cum dolo) ${ }^{82}$. Zamiar bezpośredni polega na „rozmyślnej woli naruszenia ustawy" (por. kan. $2200 \$ 1 \mathrm{CIC} / 17$ ), tj. sprawca ma świadomość normy karnej i wszystkich znamion przestępstwa, i chce go dokonać. W tym przypadku duchowny wie, jaka kara grozi za czynności seksualne wobec małoletnich w prawie kanonicznym, zna ofiarę i jej wiek, a mimo to chce dopuścić się czynności seksualnej z tą ofiarą.

\section{II.1.2. Cum culpa - przeoczone konsekwencje różnicy między regulacją łacińskią i wschodnią}

Zagadnienie, czy przestępstwo przeciwko szóstemu przykazaniu Dekalogu z małoletnim może być popełnione tylko z zamiarem bezpośrednim, domaga się bliższej analizy. Przepis art. $6 \$ 1 \mathrm{n}$. 1SST/2010 nie zawiera znamienia podmiotowego, a zatem należy przejść na ogólne znamiona przestępstwa kanonicznego ${ }^{83}$. W tym jednak miejscu zachodzi poważna różnica między prawem karnym łacińskim

\footnotetext{
${ }^{81}$ Por. M. Jasonni, Il concorso di delitti nella più recente disciplina canonistica, Il Diritto Ecclesiastico 98 (1987), s. 678-679.

${ }^{82}$ Tak na przykład, por. C. PAPAle, I delitti contro la morale..., s. 33, 44. Co do samego zagadnienia z punktu widzenia wiedzy medycznej, por. R. MedinA, Imputabilidad, eximentes, atenuantes y agravantes en los delitos sexuales de clérigos con menores (Primera parte), Anuario Argentino de Derecho Canónico 19 (2013), s. $105-151$.

${ }^{83}$ Tak też, słusznie, zob. C. PAPALE, I delitti contro la morale..., s. 33.
} 
i wschodnim. Prawo łacińskie bowiem nie zna ogólnej klauzuli winy nieumyślnej i przestępstwo tylko wtedy może być popełnione nieumyślnie, jeżeli ustawa wyraźnie tak stanowi (por. kan. 1321 \$ 2 CIC). Tymczasem w prawie wschodnim wszystkie przestępstwa mogą być popełnione także z winy nieumyślnej (por. kan. $1414 \$ 1$ CCEO) ${ }^{84}$. O ile zatem łacinnik - w oparciu o obowiązujący stan prawny - będzie mógł się dopuścić przestępstwa przeciwko szóstemu przykazaniu Dekalogu z małoletnim jedynie z zmiarem bezpośrednim (cum dolo), o tyle orientalista - nie tylko z zamiarem bezpośrednim, ale i z winy nieumyślnej (cum dolo vel cum culpa).

Przykładowo, jeśli sprawca nie jest pewien, czy ofiara skończyła lat 18 , to nie można przypisać mu zamiaru bezpośredniego ${ }^{85}$. Nie ma bowiem świadomości wszystkich znamion przestępstwa, więc nie może rozmyślnie (deliberate) przekroczyć ustawy karnej (por. kan. $1321 \S 2$ CIC, pars prima). Taki sprawca zatem, jeśli jest łacinnikiem, nie popełni przestępstwa z art. $6 \$ 1 \mathrm{n} .1 \mathrm{SST} / 2010$, a jeśli jest orientalistą - już tak (sic!).

Takie rozróżnienie nie ma, oczywiście, najmniejszego sensu i uzasadnienia. Jest to po prostu błąd ustawodawcy kościelnego, który tworząc art. $6 \$ 1 \mathrm{n} .1 \mathrm{SST} / 2010$, nie zwrócił uwagi na różnice między kodeksami obowiązującymi w Kościele - łacińskim i wschodnim. Konsekwencje jednak nie są li tylko teoretyczne. Oznacza to bowiem zawężenie kryminalizacji zachowań nagannych z małoletnimi na gruncie prawa łacińskiego ${ }^{86}$.

\footnotetext{
${ }^{84}$ Por. V. De Paolis, Komentarz do kan. 1414, w: Commento al Codice dei Canoni delle Chiese Orientali, red. P.V. Pinto, Città del Vaticano 2001, s. 1119.

${ }^{85} \mathrm{~W}$ teorii ogólnej prawa karnego mówi się o tzw. dolus quasi-eventualis w tym przypadku. Chodzi o sytuację, kiedy sprawca chce realizacji znamion czynu zabronionego, ale nie ma pewności co do znamion o charakterze statycznym (np. właśnie wiek ofiary). Na wypadek gdyby te znamiona miały miejsce, godzi się na nie. W takiej sytuacji w prawie świeckim przyjmuje się zamiar bezpośredni, gdyż sprawca chce pozostałych znamion czynu. W prawie kanonicznym jest to nie do przyjęcia, skoro bada się psychologiczny stosunek sprawcy do czynu, który popełnia.

${ }^{86}$ Projekt Księgi VI CIC z 2011 r. przewiduje już ogólną klauzulę karalności czynów popełnionych nieumyślnie; por. Pontificium Consilium de Legum Textibus, Schema..., s. 19, kan. $1321 \S 2$ in fine.
} 
II.1.3. Cum culpa, czyli cum dolo eventuali - przeoczone różnice $\mathrm{z}$ regulacją polskiego kodeksu karnego

Prawo karne kanoniczne nie zna instytucji zamiaru ewentualnego (dolus eventualis), jak na przykład kodeks karny polski (por. art. $\left.9 \$ 1 \mathrm{k} . \mathrm{k} \cdot{ }^{87}\right)$. W prawie karnym kanonicznym rolę zamiaru ewentualnego przejęła wina nieumyślna, a dokładniej nieumyślność świadoma, zwana w kanonistyce culpa proxima dolo (por. kan. $2203 \$ 1 \mathrm{CIC} / 17$, część druga), czyli lekkomyślność (por. kan. $1326 \$ 1$ n. 3 CIC) ${ }^{88}$.

Skoro zaś przestępstwa $\mathrm{z}$ art. $6 \$ 1 \mathrm{n}$. $1 \mathrm{SST} / 2010$ nie można popełnić z winy nieumyślnej, to wszystkie te zachowania, które sądy polskie będą traktować jako popełnione z zamiarem ewentualnym, będą niekaralne w prawie kanonicznym łacińskim (sic!). Do czasu zmiany prawa powszechnego Kościoła w tym zakresie i wprowadzenie generalnej klauzuli winy nieumyślnej w kan. $1321 \$ 2$ CIC ustawodawca partykularny polski powinien odpowiednio spenalizować tego typu czyny w Kościele w Polsce. Tymczasem wytyczne KEP milczą, niestety, na ten temat.

Czy zatem nie jest możliwa jakakolwiek reakcja kanonicznokarna w tych przypadkach? Wydaje się, że ordynariuszowi trudno będzie uzasadnić zastosowanie kary kanonicznej, chyba że powołując się na zasadę ratione peccati z kan. 1401 n. 2 CIC. Kościół bowiem zawsze może reagować na grzech ciężki swoich wiernych, nawet jeśli nie został on stypizowany jako przestępstwo kanoniczne ${ }^{89}$. Z pewnością jednak możliwa jest reakcja dyscyplinarna.

\footnotetext{
${ }^{87}$ Przepis ten stanowi: „Czyn zabroniony popełniony jest umyślnie, jeżeli sprawca ma zamiar jego popełnienia, to jest chce go popełnić [jest to zamiar bezpośredni P.S.] albo przewidując możliwość jego popełnienia, na to się godzi [jest to zamiar ewentualny - P.S.]".

${ }^{88}$ Zob. A. D’Auria, L'imputabilità nel diritto penale canonico, Roma 1997, s. 126-128.

${ }^{89}$ Zasada ta wywodzi się jeszcze z dekretału Novit ille papieża Innocentego III (1161-1216) z 1204 r. (X,II,1,13); por. M. Мү RсHA, Problem grzechu w karnym ustawodawstwie kanonicznym, Prawo Kanoniczne 29 (1986) nr 1-2, s. 57, 60-73, 76-77; J. Syry JCZy K, Sankcje w Kościele: część ogólna, komentarz, Warszawa 2008, s. 39-40; Tenże, Kanoniczne prawo karne: część szczególna, Warszawa 2003, s. 183. Analiza
} 


\section{II.2. Sylwetka psychologiczna pedofila a możliwość powołania się na chorobę psychiczną jako okoliczność wyłączającą lub zmniejszającą zawienienie czynu}

W odniesieniu do przestępstw cięższych contra mores bardzo trudne jest powołanie się przez sprawcę na którąkolwiek okoliczność wyłączającą lub umniejszającą zawinienie czynu (por. kan. 1323 i kan. 1324 CIC, kan. 1415 CCEO $)^{90}$.

W myśl kan. 1322 CIC osoby habitualnie pozbawione rozumu są uważane za niezdolne do popełnienia przestępstwa (delicti incapaces). Natomiast zgodnie z kan. 1323 n. 6 CIC osoby nie posiadające aktualnie rozumu $\mathrm{w}$ chwili popełniania przestępstwa nie podlegają karze kanonicznej. Zatem brak całkowity używania rozumu - tak habitualny, jak i aktualny - jest okolicznością czy to wyłączającą zawinienie czynu, czy też je umniejszającą, jeżeli brak ten był niezupełny (por. kan. $1321 \$ 1 \mathrm{n} .1 \mathrm{CIC}$ ).

Ten brak rozumu czy też jego niepełne używanie może wynikać $z$ choroby psychicznej. Jednak pedofilowi trudno będzie przeprowadzić dowód na taką okoliczność. Z praktyki klinicznej wynika, że $60 \%$ pedofilów ma co prawda zaburzenia osobowości, ale nie stanowią one choroby psychicznej ${ }^{91}$. Podobnie należy ocenić zaburzenia lękowe, dystymię (depresyjne zaburzenie osobowości), zespoły otępienne i alkoholizm, także występujące u pedofilów w sensie medycznym ${ }^{92}$. Psychika pedofila jest niedojrzała (jak u dziecka), narcystyczna, stąd jego pociąg seksualny do dzieci ${ }^{93}$. Jednak takiej psychiki nie można uznać za stan chorobowy. Oczywiście, zdarzają się również pedofile

systematyczna tego elementu teologicznego przestępstwa kanonicznego, zob. P. SкоNIECZNY, La compartecipazione..., s. 216-224, a zwłaszcza s. 219.

${ }^{90}$ Por. C. Dezutto, Le principali obiezioni..., s. 99. Wprost wskazuje się w literaturze na niemożliwość powoływania się na okoliczności z kan. 1323 n. 1, 4, 5 i 7 oraz kan. $1324 \$ 1$, n. 4, 5, 6, 9 CIC; por. R. MedinA, Imputabilidad, eximentes, atenuantes y agravantes en los delitos sexuales de clérigos con menores, „Anuario Argentino de Derecho Canónico" 20 (2014), s. 187, 194.

${ }^{91}$ Zob. I. Łucka, A. Dziemian, Pedofilia..., s. 123.

${ }^{92}$ Por. tamże, s. 123.

${ }^{93}$ Zob. tamże, s. 123. 
o upośledzeniu umysłowym ${ }^{94}$, a wówczas przypadki takie należy odrębnie potraktować z możliwością zastosowania kan. 1322 czy też kan. 1323 n. 6 oraz kan. $1324 \$ 1$ n. 1 CIC.

W każdym razie wyłączenie odpowiedzialności kanonicznokarnej z powodu choroby psychicznej sprawcy czynu zabronionego z art. 6 $\$ 1$ n. 1 SST/2010 oznacza konieczność zadeklarowania zaciągnięcia przez niego na tej podstawie przeszkody do przyjęcia czy też wykonywania święceń (por. kan. 1041 n. 1, $1044 \$ 1$ n. 1 oraz $\$ 2$ n. 2 CIC; kan. $762 \$ 1$ n. 1,763 n. 1 i 3 CCEO $)^{95}$.

\section{II.3. Inne okoliczności wyłączające lub zmniejszające zawinienie czynu}

\section{II.3.1. Nieznajomość ustawy karnej}

Przede wszystkim w odniesieniu do delicta graviora sprawcy trudno będzie wykazać nieznajomość ustawy karnej w tym przedmiocie. Duchowni i alumni seminariów duchownych mają bowiem obowiązek ich poznania w kontekście obowiązku celibatu kościelnego ${ }^{96}$.

Co więcej, nieznajomość ustawy karnej w tym zakresie będzie musiała być uznana za ignorantia crassa vel supina z kan. 1325 CIC (nieznajomość ciężko zawinioną), na którą duchowny nie może się powoływać. Taka nieświadomość czy błąd dotyczą przecież materii de sexto, a ta jest znana duchownemu jako zabroniona w związku z jego zobowiązaniem do zachowywania ustawy o celibacie kościelnym

\footnotetext{
${ }^{94}$ Por. tamże, s. 123.

${ }^{95}$ Zob. R.E. Jenkins, On the Suitability of Establishing Clerical Sexual Abuse of Minors (c. $1395 \$ 2$ ) as an Irregularity ex delicto to the Reception and Exercise of Orders, Periodica de re canonica 94 (2005), s. 278.

${ }^{96}$ Por. kan. 279 CIC, kan. 372 CCEO; Congregazione della Dottrina della FEDE, Lettera Circolare Tra le importanti responsabilità per aiutare le Conferenze Episcopali nel preparare Linee guida per il trattamento dei casi di abuso sessuale nei confronti di minori da parte di chierici, 3.05.2011, AAS 103 (2011) 406-412, n. I lit. c); przekład polski: http://www.vatican.va/roman_curia/congregations/cfaith/ documents/rc_con_cfaith_doc_20110503_abuso-minori_pl.html (2016-09-30).
} 
(por. kan. 277 CIC, kan. 373-374 CCEO) ${ }^{97}$. W ten sposób kan. 1325 CIC (kan. $1414 \$ 1$ CCEO in fine) wyłącza zastosowanie jakiejkolwiek okoliczności łagodzącej wobec duchownego dopuszczającego się przestępstwa contra mores ${ }^{98}$.

\section{II.3.2. Zgoda ofiary}

Z wyżej wskazanych względów (obowiązek celibatu kościelnego) nie może się duchowny powoływać na zgodę małoletniego co do dokonania czynności seksualnej. Taka zgoda nie ma żadnego znaczenia prawnego $^{99}$. Sprawca popełnia przestępstwo, tym bardziej że jako duchowny zobowiązany jest do celibatu kościelnego.

\section{II.3.3. Prowokacja ze strony małoletniego}

Również z tego względu nie będzie możliwe odwołanie się do prowokacji małoletniego, co często się zdarza w przypadku nastolatek zakochanych w duszpasterzach. Prawo karne kanoniczne zna co prawda taką okoliczność umniejszającą zawinienie czynu sprawcy poważnej i niesprawiedliwej prowokacji (graviter et iniuste provocans - kan. $1324 \$ 1$ n. 7 CIC; por. kan. 1415 CCEO). Jednakże taka prowokacja ze strony małoletniego nigdy nie będzie niesprawiedliwa. Trudno też sobie wyobrazić, by stan psychiczny duchownego, prowokowanego do naruszenia celibatu kościelnego z małoletnim, był tak słaby, by nie był on w stanie odeprzeć te zachęty i prowokacje ${ }^{100}$. Oczywiście, nie można wyłączyć tego typu okoliczności z kan. 1324 $\$ 1$ CIC, ale godność duchownego w kontekście przykazania szóstego Dekalogu (por. kan. $1326 \$ 1$ n. 2 CIC) oraz jego lekkomylnoślność

\footnotetext{
${ }^{97}$ Por. C. Dezutto, Le principali obiezioni..., s. 99. W przypadku jednak powodzenia dowodu odnośnie do nieznajomości ustawy karnej w tym zakresie należałoby zastosować kan. $1389 \$ 2$ CIC; por. R. MEdinA, Imputabilidad..., s. 188.

${ }^{98}$ Por. C. Dezutto, Le principali obiezioni..., s. 99; R. Medina, Imputabilidad..., s. 191-193.

${ }^{99}$ Zob. D.G. Astigueta, Le facoltà concesse alla Congregazione per il Clero, Periodica de re canonica 99 (2010), s. 10; D. Borek, Sextum Decalogi praeceptum..., s. 78-79; J. Syry JCzy K, Kanoniczne prawo karne..., s. 165.

${ }^{100}$ Por. C. Dezutto, Le principali obiezioni..., s. 98.
} 
w tej materii (por. kan. $1326 \$ 1$ n. 3 CIC) - będą utrudniały w tym zakresie pomyślne przeprowadzenie dowodu na korzyść oskarżonego duchownego.

\section{ZNAMIĘ LEGALNE I KARALNOŚĆ}

\section{III.1. Znamię legalne, czyli zagrożenie karą przestępstw contra mores}

\section{III.1.1. Dwa stopnie wymierzania sankcji karnej}

Przestępstwa contra mores, w tym - oczywiście - przestępstwo przeciwko szóstemu przykazaniu Dekalogu z małoletnim, są zagrożone karą obligatoryjną ferendae sententiae, nieokreśloną - według ciężkości przestępstwa, niezarezerwowaną, nie wyłączając wydalenia ze stanu duchownego wobec łacinników, a depozycji - wobec orientalistów (por. art. $6 \$ 2$ SST/2010) ${ }^{101}$.

Rozwijając tę ogólną normę sankcjonującą, list okólny Kongregacji Doktryny Wiary Tra le importanti responsabilità z dnia 3 maja 2011 r. stanowi o dwóch stopniach sankcji ${ }^{102}$. Pierwszy stopień polega na ograniczeniu posługi ministerialnej - bądź tylko zakazując pracy z małoletnimi, bądź też w ogóle zakazując publicznej posługi ministerialnej przez duchownego uznanego za winnego popełnionego przestępstwa kanonicznego. Aby wzmocnić te zakazy, można dodać nakaz karny (por. kan. 1319 CIC, kan. $1406 \$ 1$ CCEO).

Drugi stopień to wymierzenie kary, zwłaszcza kary wydalenia ze stanu duchownego. Zagrożenie karą wydalenia ze stanu duchownego, a więc karą wiążącą na stałe, kiedy kara za dane przestępstwo nie jest określona - jest wyjątkiem od kan. 1349 CIC (kan. 1409 \$ 2 w zw.

\footnotetext{
${ }^{101}$ Por. E. Miragoli, La "pena giusta" nei casi di delicta graviora, Quaderni di diritto ecclesiale 25 (2012), s. 356-368.

102 Por. Congregazione della Dottrina della Fede, Lettera Circolare Tra le importanti responsabilità..., n. II,5. Należy zwrócić uwagę na liczne błędy i nieścisłości tłumaczenia na język polski tego dokumentu. Zob. Th.J. Green, CDF Circular Letter on Episcopal Conference Guidelines for Cases of Clerical Sexual Abuse of Minors: Some Initial Observations, The Jurist 73 (2013), s. 163-164.
} 
z kan. $1402 \$ 2$ CCEO), zabraniającym w takich wypadkach wymierzania tego typu $\operatorname{kar}^{103}$. Można jednak podnosić, czy czasami nie lepiej by było dla społeczeństwa, by zdeprawowany seksualnie duchowny pozostał w stanie duchownym pod nadzorem przełożonych kościelnych (vigilantia z kan. 1428 CCEO; por. kan. $1946 \$ 2$ n. 2 oraz kan. 1957 CIC/17) i w ten sposób nie mógł dalej szkodzić małoletnim ${ }^{104}$.

\section{III.1.2. Wydalenie zakonnika $\mathrm{z}$ instytutu zakonnego}

Popełnienie przestępstwa przeciwko szóstemu przykazaniu Dekalogu z małoletnim może spowodować - oprócz nałożenia kary kanonicznej - wydalenie zakonnika $\mathrm{z}$ instytutu zakonnego, ale z możliwością innego zaradzenia poprawie sprawcy (por. kan. 695 CIC) ${ }^{105}$. Podobna sankcja dotyczy członka instytutu świeckiego (kan. 729 CIC)

\footnotetext{
${ }^{103}$ Jak ujawniał ks. Charles Scicluna, 20\% oskarżonych, których sprawy trafiły do Kongregacji Doktryny Wiary, zostało już wcześniej osądzonych na szczeblu diecezjalnym. W stosunku do kolejnych $60 \%$ nie przeprowadzono procesu ze względu na zaawansowany wiek, stosując jednak wobec nich środki dyscyplinarne, takie jak zakaz publicznego odprawiania Mszy św., odebranie upoważnienia do słuchania spowiedzi oraz „nakaz życia w odosobnieniu i na modlitwie”. W 10\% przypadków, „wyjątkowo poważnych i przy miażdżących dowodach”, papież podjął decyzję o wydaleniu ze stanu duchownego. Ostatnie 10\% dotyczyło duchownych, którzy sami poprosili o dyspensę od celibatu kościelnego; prośby te zostały szybko przyjęte. Por. G. Cardinali, Ch. Scicluna, Intervista..., tamże; P. Bieliński, Kościót..., tamże. Ponadto zob. dane statystyczne podane we wprowadzeniu.

${ }^{104}$ Tak właśnie zob. Th.J. Green, CDF Circular Letter..., s. 164. Taka jest też praktyka niektórych instytutów zakonnych, które doprowadzają co prawda do wydalnia sprawcy ze stanu duchownego, ale pozostaje on nadal członkiem instytutu, czyli pod władzą (i nadzorem) swoich przełożonych zakonnych.

${ }^{105}$ Na podstawie prawa kanonicznego powszechnego nie można uważać, że wydalenie z instytutu zakonnego jest karą ekspiacyjną (tak zaś właśnie por. D. BoReK, Sextum Decalogi praeceptum..., s. 81-82). Ta reakcja dyscyplinarna bowiem nie znajduje się w katalogu kan. $1336 \$ 1$ w zw. z kan. $1312 \$ 1$ i 2 CIC. Ustawy karne z kolei należy interpretować ściśle (por. kan. 18 CIC). Oczywiście, instytut życia konsekrowanego może w prawie własnym postanowić inaczej (por. kan. $1312 \$ 2$ w zw. z kan. 596 CIC).
} 
oraz stowarzyszenia życia apostolskiego (kan. 746 CIC) ${ }^{106}$. Jednakże ta reakcja dyscyplinarna nie dotyczy postulantów czy nowicjuszy ${ }^{107}$.

Taka regulacja wobec zakonników budzi zasadnicze zastrzeżenia, biorąc pod uwagę najnowsze nauczanie papieskie. Papież św. Jan $\mathrm{Pa}-$ weł II wyraźnie stwierdził w przemówieniu z dnia 23 kwietnia 2003 r.: „[...] w kapłaństwie i życiu zakonnym nie ma miejsca dla kogoś, kto mógłby wyrządzić krzywdę młodzieży"108. W życiu konsekrowanym, które przecież zasadza się między innymi na ślubie czystości, nie może być tolerowania jawnego i do tego tak okropnego złamania tego ślubu. Zachodzi zatem wyraźna sprzeczność między nauczaniem papieży odnośnie do nadużyć seksualnych wobec małoletnich, dokonywanych przez duchownych czy członków instytutów życia konsekrowanego, a regulacją z kan. 695 CIC, które to postępowanie niekoniecznie musi zakończyć się wydaleniem z instytutu zakonnego. Dlatego, de lege ferenda, kan. $695 \$ 1$ CIC powienien być pilnie zmieniony ${ }^{109}$.

\section{III.1.3. Uwagi de lege ferenda - kara latae sententiae i przeszkoda do przyjęcia święceń?}

De lege ferenda warto by rozważyć, czy nie należałoby przewidzieć również karę latae sententiae dla duchownego czy innego wiernego za czyn o naturze pedofilskiej sensu stricto (z małoletnimi do 13. roku życia). Sprawca przecież wyrządza małoletniej ofierze wielkie zło, z którym prawdopodobnie będzie musiała się ona borykać przez całe

\footnotetext{
${ }^{106}$ Zob. F.R. Aznar Gil, El delito..., s. 491; D. Borek, Sextum Decalogi praeceptum..., s. 60; A. Borras, Les sanctions dans l'Église. Commentaire des Canons 1311-1399, Paris 1990, s. 193-194; E. Gómez Martín, El delito..., s. 187-188; W. Rees, Sexueller Missbrauch..., 401.

${ }^{107}$ Por. E. Gómez Martín, El delito..., s. 188.

108, „...] nel sacerdozio e nella vita religiosa non c'è posto per chi potrebbe far del male ai giovani” (Giovanni PAOLO II, Discorso Permettetemi ai partecipanti alla riunione interdicasteriale con i Cardinali degli Stati Uniti d'America, 23.04.2003, http://w2.vatican.va/content/john-paul-ii/it/speeches/2002/april/documents/hf_jp-ii_spe_20020423_usa-cardinals.html [2016-10-01], n. 3,2).

${ }^{109} \mathrm{O}$ innym problemie de lege ferenda na tle przestępstwa pornografii dziecięcej, zob. P. SKonieczny, Przestępstwo cięższe pornografii dziecięcej..., III.3.
} 
życie. Wyrządzone przez duchownego zło może też wpłynąć (i często wpływa) na jej stosunek do Pana Boga i do Kościoła. Przestępstwo zatem tamuje misję Kościoła. Stąd przewidzenie kary (np. interdyktu) latae sententiae mogłoby pełnić podobną rolę - też prewencyjną - jak ekskomunika latae sententiae w przypadku dokonania aborcji (por. kan. 1398 CIC). W prawie wschodnim mogłaby to być rezerwacja grzechu analogicznie do rozgrzeszenia z grzechu dokonania aborcji (por. kan. $728 \$ 2$ CCEO). Reakcja prawnokarna w postaci kary latae sententiae byłaby też stosowna wobec dużego utajnienia tego typu spraw i poczucia bezkarności sprawcy, jak wskazują badania ${ }^{110}$.

W związku z pojawiającymi się w praktyce Kongregacji Doktryny Wiary przypadkami czynów zabronionych przeciwko szóstemu przykazaniu Dekalogu z małoletnim, popełnionymi przed przyjęciem święceń, ale także dla lepszej ochrony misji Kościoła - należy ponadto rozważyć wprowadzenie przeszkody do przyjęcia święceń w kan. 1041 CIC (kan. $762 \$ 1$ CCEO), a także ich wykonywania w kan. 1044 CIC (kan. 763 CCEO) ${ }^{111}$. Uznawanie bowiem tego typu przypadków za „przestępstwa”, kiedy sprawca czynu nie był jeszcze duchownym - jest niezgodne z zasadą praworządności z kan. 221 CIC (kan. 24 CCEO). Wprowadzenie tej przeszkody byłoby celowe, nawet gdyby przestępstwo przeciwko szóstemu przykazaniu Dekalogu z małoletnim przestało być indywidualne i objęło również świeckich. Przeszkoda bowiem ma charakter obiektywny i dotyczy nie popełnionych przestępstw, lecz czynów zabronionych ${ }^{112}$, a zatem niezależnie od tego, czy sprawca zawinił czyn. Wprowadzenie tego typu przeszkody należałoby jednak ograniczyć do czynów o naturze pedofilskiej sensu stricto (z małoletnimi do 13. roku życia), gdyż czyn zabroniony w kan. 1395 $\S 2$ CIC i art $6 \S 1$ n. 1 SST/2010 jest zbyt szeroko ujęty ${ }^{113}$.

\footnotetext{
${ }^{110}$ Por. I. Łucka, A. Dziemian, Pedofilia..., s. 125.

${ }^{111}$ Zob. R.E. Jenkins, On the Suitability..., s. 277, 339-340.

112 Tak wyraźnie ostatnio, por. Pontificium Consilium de Legum Textibus, Interpretatio authentica ad can. 1041, nn. 4-5 CIC, 31.05.2016, „L'Osservatore Romano" z 16.09.2016, s. 4.

113 Tak słusznie, por. R.E. JEnkins, On the Suitability..., s. 330.
} 


\section{III.2. Przedawnienie karnokanoniczne przestępstw contra mores}

W myśl art. $7 \$ 1$ SST/2010 przedawnienie karnokanoniczne przestępstw contra mores - podobnie jak wszystkich delicta graviora wynosi 20 lat. Przedmiotem tego przedawnienia kanonicznokarnego jest osądzenie przestępstwa, czyli wszczęcie postępowania karnego. Jednak to przedawnienie może zostać deregowane przez Kongregację Doktryny Wiary w poszczególnych przypadkach. Chodzi o wzmocnienie funkcji ekspiacyjnej kary kanonicznej i uniknięcie zgorszenia.

Co do biegu przedawnienia, należy stosować zasady ogólne, o których w kan. $1362 \$ 2$ CIC i kan. $1152 \$ 3$ CCEO (por. art. 7 \$ SST/2010, in princ.). Jednakże wyjątek dotyczy przestępstwa przeciwko szóstemu przykazaniu Dekalogu z małoletnim (art. $6 \$ 1 \mathrm{n} .1 \mathrm{SST} / 2010)$. W tym bowiem przypadku ów termin 20-letni zaczyna biec od dnia, w którym małoletni kończy lat 18 (por. art. $7 \$ 2$ SST/2010, in fine).

Natomiast nie jest jasne, jak należy liczyć ów termin przedawnienia co do przestępstwa popełnionego na szkodę osoby trwale ograniczonej w używaniu rozumu ${ }^{114}$. Przecież będą to głównie osoby pełnoletnie, a zatem termin przedawnienia nie zacznie biec od dnia, w którym skończą 18 lat. Przepis art. $7 \$ 2$ SST/2010 nie odróżnia tych dwóch sytuacji.

Krytycznie rzecz ujmując, konstrukcja derogacji przedawnienia kanonicznokarnego jest pokraczna z teoretycznego punktu widzenia. Przede wszystkim może spowodować arbitralność i uznaniowość $\mathrm{w}$ jej stosowaniu. O wiele zaś poprawniejszą teoretycznie jest koncepcja przestępstw kanonicznych nieprzedawnialnych ${ }^{115}$. Takie przestępstwa nieprzedawnialne były znane kodeksowi z 1917. Były to zgodnie z kan. 1703 oraz kan. $1555 \$ 1$ CIC/17 przestępstwa zarezerwowane Św. Oficjum, odpowiadające delicta graviora.

W ten sposób prawo karne kanoniczne również byłoby bardziej wiarygodne wobec prawa karnego państwowego, które stosuje instytucję wyłączenia zatarcia skazania, jeśli chodzi o przestępstwa

\footnotetext{
114 Zob. G. Puntillo, „Delicta graviora” e Legislazione canonica di emergenza, Apollinaris 84 (2011), s. 385.

115 Por. tamże, s. 385; J. Syry JCZYk, Sankcje..., s. 321.
} 
popełnione na szkodę małoletnich do 15. roku życia (por. art. 106a k.k.). Dłuższy jest też termin przedawnienia karalności takiego przestępstwa, który nie może nastąpić przed ukończeniem przez taką małoletnią ofiarę 30. roku życia (por. art. $101 \$ 4$ k.k.).

W końcu trzeba też zauważyć problem intertemporalny. Pod rządem bowiem poprzednich przepisów z 2001 r. terminy przedawnienia były krótsze, a też inna była instytucja upoważnienia Kongregacji „derogowania terminów przedawnienia” (la facoltà di derogare ai termini della prescrizione ${ }^{116}$. To wszystko może wpłynąć na wybór ustawy względniejszej (por. kan. $1313 \$ 1$ CIC) dla sprawcy przestępstwa przeciwko szóstemu przykazaniu Dekalogu z małoletnim ${ }^{117}$.

\section{III.3. Szczególne zagadnienia proceduralne}

Przestępstwa cięższe contra mores są zarezerwowane Kongregacji Doktryny Wiary (por. art. $6 \$ 1$ SST/2010 in princ.). Rezerwacja ta za przedmiot ma osądzenie i tylko osądzenie przestępstwa contra mores (nałożenia bądź zadeklarowania kary, a zatem tylko na forum zewnętrznym). Rezerwacja przestępstwa Kongregacji nie dotyczy zniesienia kary. Byłaby to bowiem rezerwacja kary Stolicy Apostolskiej, co w przypadku przestępstw contra mores nie ma miejsca w obecnym stanie prawnym.

W końcu przestępstwo przeciwko szóstemu przykazaniu Dekalogu $\mathrm{z}$ małoletnim (art. $6 \$ 1 \mathrm{n} .1 \mathrm{SST} / 2010$ ) jest przedmiotem upoważnienia specjalnego według Listu okólnego In data 30 gennaio z dnia 18 kwietnia $2009^{118}$, umożliwiając wydalenie ze stanu duchownego bez trybu sądowego (ponadto por. art. $21 \S 1 \mathrm{n} .1 \mathrm{SST} / 2010)$.

\footnotetext{
116 Zob. Giovanni Paolo II, Facoltà di derogare dalla prescrizione, 7.11.2002, Ius Ecclesiae 16 (2004), s. 320.

${ }^{117}$ Por. J.L. SÁnChez-Girón Renedo, Normas procesales en la regulación de gravioribus delictis dal año 2010, Estudios eclesiásticos 86 (2011), s. 721-722.

118 Zob. Congregazione Per il Clero, Lettera circolare In data 30 gennaio, Prot. N. 2009 0556, sulle alcune potestà ricevute dal Sommo Pontefice, 18.04.2009, Enchiridion Vaticanum, t. 26, s. 286-297, nb. 407-450; ponadto rozpowszechniony w: http://www.episkopat.pl/?a=dokumentyKEP\&doc=200968_0 (2009.12.19), Ius Canonicum 50 (2010), s. 659-669.
} 
Do bolesnego i przykrego postępowania kanonicznokarnego nie musi dojść. Zgodnie bowiem z postanowieniami listu okólnego Kongregacji Nauki Wiary Tra le importanti responsabilità z 3 maja $2011 \mathrm{r}$. w niektórych przypadkach będzie możliwe, na prośbę sprawcy, zwolnienie z obowiązków stanu duchownego wraz z dyspensą od celibatu kościelnego ${ }^{119}$.

\section{Zakończenie}

Skandal wykorzystywania seksualnego małoletnich przez duchownych spowodował zmiany w ustawodawstwie Kościoła i swego rodzaju renesans prawa karnego kanonicznego ${ }^{120}$. Kościół dużo zrobił, aby chronić misję i wiarygodność przekazu Ewangelii Jezusa Chrystusa. Jednakże z technicznego punktu widzenia obowiązująca regulacja nie jest doskonała. Warto zatem dokonać dalszych zmian ustawy karnej w tym zakresie - dla dobra dusz (por. kan. 1752 CIC).

\section{The more grave delict against the Sixth Commandment of the Decalogue with a minor: some observations de lege lata and de lege ferenda}

The Author comments on the constituent elements (objective, subjective and legal) of the offence specified in Art. $6 \$ 1 \mathrm{n} .1 \mathrm{SST} / 2010$. He indicates the change in the aim of penal protection: from the celibate's duty in can. $1395 \$ 2$ CIC to mores in Art. 6 SST/2010. Following the canonical tradition, he calls for the extension to the lay Christian faithful of the element concerning the agent. He approves of the extended and theological meaning of the offence ('the commission of the delict against the Sixth Commandment of the Decalogue'). The ecclesiastical legislator, however, has needlessly specified that a minor is someone below the age of eighteen years. In fact, this definition accords with the legal definition of a minor specified in can. $97 \$ 1 \mathrm{CIC}$. On

\footnotetext{
${ }^{119}$ Por. Congregazione della Dottrina della Fede, Lettera Circolare Tra le importanti responsabilità..., n. II,6. Zob. Th.J. Green, CDF Circular Letter..., s. 164. ${ }^{120}$ Zob. P. SKonieczny, Przestępstwa przeciwko Najświętszej Eucharystii: komentarz do art. 2 „Norm” Kongregacji Nauki Wiary „De gravioribus delictis” z 2001 r., Prawo Kanoniczne 54 (2011) nr 3-4, s. 284.
} 
the other hand, it would be a good idea to distinguish a paedophile sensu stricto from an ephebophile, and to determine the punishment accordingly. Moreover, according to the Author the habitu element is not justified in the case of the delict's other kind of victim ('habitually lacks the use of reason'). With reference to the subjective element, the Author notes the difference between the Latin code (the delict is only cum dolo) and the Eastern one (the delict can also be cum culpa), and the secular criminal codes with their so-called 'eventual intention' (dolus eventualis, e.g. the Polish criminal code). With regard to penal sanctions, the Author calls for a penalty latae sententiae, an impediment to ordination in the case of the paedophile sensu stricto, and the adaptation of can. 695 CIC to Art. 6 SST/2010. Finally, he suggests the abandonment of derogation from prescription, and the application of imprescriptibility to delicta graviora.

SŁOWA KLUCZOWE: pedofilia; przestępstwo przeciwko szóstemu przykazaniu Dekalogu; delicta graviora; Sacramentorum sanctitatis tutela z 2010 r., art. $6 \$ 1 \mathrm{n}$. 1 oraz $\$ 2$ SST/2010

Key words: paedophilia; delict against the Sixth Commandment of the Decalogue; delicta graviora; 2010 Sacramentorum sanctitatis tutela, art. $6 \$ 1 \mathrm{n} .1$ and $\$ 2$ SST $/ 2010$

\section{Nota o Autorze:}

O. DR hAB. Piotr SKonieczny OP - doktor habilitowany nauk prawnych w zakresie prawa kanonicznego; od 2015 roku kierownik Katedry Kanonicznego Prawa Karnego na Wydziale Prawa Kanonicznego Uniwersytetu Papieskiego Jana Pawła II w Krakowie oraz od 2016 roku wykładowca w Kolegium Filozoficzno-Teologicznym Prowincji Polskiej OO. Dominikanów w Krakowie. 